\title{
Surgical clinical trials with non-inferiority design: a cross-sectional bibliometric analysis
}

\author{
Chi Shu ${ }^{1,2,3}$, Bin Huang ${ }^{1}$, Ding Yuan ${ }^{1}$, Yi Yang ${ }^{1}$, Xiaojiong Du ${ }^{1}$, Yazhou He ${ }^{4}$, Xin Chen ${ }^{4}$, Jichun Zhao ${ }^{1}$ \\ ${ }^{1}$ Department of Vascular Surgery, West China Hospital, Sichuan University, Chengdu, China; ${ }^{2}$ West China School of Medicine, Sichuan University, \\ Chengdu, China; ${ }^{3}$ Department of Vascular Surgery, Toronto General Hospital, Toronto, ON, Canada; ${ }^{4}$ Department of Oncology, West China School \\ of Public Health and West China Fourth Hospital, Sichuan University, Chengdu, China \\ Contributions: (I) Conception and design: X Chen, C Shu, B Huang; (II) Administrative support: X Chen, Y Yang; (III) Provision of study materials \\ or patients: X Chen, Y Yang; (IV) Collection and assembly of data: All authors; (V) Data analysis and interpretation: All authors; (VI) Manuscript \\ writing: All authors; (VII) Final approval of manuscript: All authors. \\ Correspondence to: Jichun Zhao. Department of Vascular Surgery, West China Hospital, Sichuan University, 37 Guo Xue Alley, Chengdu 610041, \\ China. Email: zhaojc3@163.com; Xin Chen. Department of Oncology, West China School of Public Health and West China Fourth Hospital, \\ Sichuan University, 16 Ren Min South Street, Chengdu 610041, China. Email: liangchaokaiji@foxmail.com.
}

\begin{abstract}
Background: Wide-spread concerns have been raised about possible bias in published surgical noninferiority trials. Therefore, we performed a comprehensive bibliometric analysis to identify the existence of bias, and provided recommendations for future non-inferiority trials.

Methods: Databases including MEDLINE, Embase, and the Cochrane Central Register of Controlled Trials were systematically searched (last update on 27 April 2020) to include published phase II and phase III non-inferiority surgical trials. We collected general information and parameters associated with trial design. The association between extracted factors and establishment of non-inferiority was then analyzed.

Results: A total of 347 trials were included in this study. Only 13 (3.7\%) trials reported the pre-specified non-inferiority margin in registration, and 99 (28.5\%) trials justified margin selection in ultimate trial publications. A significant association was found between industry funding and increased odds of achieving non-inferiority [odds ratio (OR): $1.17,95 \%$ confidence interval (CI): 1.06 to $1.30, \mathrm{P}=0.001$ ]. Moreover, trials which had been presented in conferences were less likely to claim non-inferiority (OR: $0.83,95 \%$ CI: 0.69 to 0.99, $\mathrm{P}=0.035)$.

Conclusions: Our study was the first quantitative analysis revealing the presence of biases in findings of existing surgical non-inferiority trials, which could possibly mislead surgeons' clinical decision making. We suggest improving reporting of detailed study design especially funding sources as well as margin justification for future trials. We also encourage conference presentation of ongoing trials prior to the ultimate publication.
\end{abstract}

Keywords: Non-inferiority; design; bias; surgical trial; bibliometric analysis

Submitted May 12, 2021. Accepted for publication Aug 11, 2021.

doi: 10.21037/atm-21-2626

View this article at: https://dx.doi.org/10.21037/atm-21-2626

\section{Introduction}

Non-inferiority design has been deployed in a growing number of surgical clinical trials. It is the optimal choice for investigating new surgical procedures which may not present significant clinical superiority but offers certain advantages such as increased cost-efficiency, ease of operation, and reduced invasiveness (1). To date, a few surgical novel techniques, such as the robot-assisted and laparoscopic procedures $(2,3)$, have been recommended by official guidelines based on the findings of non-inferiority trials. 
Concluding non-inferiority is based on comparison between confidence intervals of treatment effects and predefined and clinically acceptable margins, known as noninferiority margins. One of the most challenging points in non-inferiority design is margin justification since it should balance both clinical and statistical perceptions (4). Theoretically, the probability of establishing non-inferiority should be independent from pre-specified parameters except for the type II error ( $\beta$ ) or statistical power under the alternative hypothesis. However, there have been widespread concerns regarding the validity of established noninferiority, especially on account of the arbitrary definition of non-inferiority (5), where biases could stem from $(6,7)$. An earlier systematic review found that even in highquality journals, non-inferiority design of clinical trials was reported inconsistently and did not follow official recommendations (8). Biased findings of non-inferiority, if approved by guidelines, could potentially mislead surgeons in clinical decision-making and eventually result in patients receiving inferior surgical treatments. However, quantitative evidence is still lacking, leaving this issue unsolved.

To determine the existence of bias, we explored the external factors that influence the establishment of noninferiority by systematically surveying and analyzing the characteristics of published surgical clinical trials.

We present the following article in accordance with the PRISMA reporting checklist (available at https://dx.doi. org/10.21037/atm-21-2626).

\section{Methods}

\section{Search strategy and trial selection}

Databases including MEDLINE, Embase, and the Cochrane Central Register of Controlled Trials were systematically searched (last update on 27 April 2020, detailed strategy presented in Table S1) with a limitation to publications in the English language. The search was restricted to clinical trials in MEDLINE and Embase. The registry identifier and references of included studies were also cross-checked for additional trials.

All retrieved records were screened by two reviewers (C.S. and B.H.). We included non-inferiority trials that investigated surgical procedures of treatment purposes in at least one treatment arm based on the recommendations from the PubMed queries (9), and excluded trials regarding the diagnostic, cosmetic, and obstetric procedures (10). The inclusion criteria were as follows: completed or ongoing trials with published results; trials aiming to prove noninferiority of a new treatment (procedure, technique, material, and so on) to a conventional one, and at least one treatment was surgical related; trials reporting whether the non-inferiority was established. For multiple publications with the same registry identifier, only the one reporting the ultimate findings of the primary outcome was included. Subgroup and post hoc analyses were not eligible. Any discrepancies were solved by discussion with a senior surgeon (J.Z.) and an epidemiologist (D.Y.).

\section{Data extraction}

A standard data extraction of included studies was performed by one author (C.S.) with an Excel form and checked by a second author (X.C.). Discrepancies were reviewed and discussed to reach agreement. Essential characteristics of the eligible studies were abstracted by two reviewers (C.S. and X.C.) independently, including first author, publication year, journal name and impact factor in 2019, single or multi-center trial, trial status (completed, interim, or terminated), trial registry number, surgical specialty (e.g., cardiovascular, digestive, urogenital, orthopedic, and so on), follow-up time (months), primary outcome (e.g., event free survival, surgical success, late luminal loss, etc.), funding source (industry or non-industry), conference presentation, and declaration of competing interests.

We also collected methodologic parameters associated with study design including outcome event rate, 1-sided type I error $(\alpha)$, type II error $(\beta)$, non-inferiority margin reported as both absolute differences such as rate difference and relative effect sizes such as hazard ratios (HR), odds ratios (OR), and risk ratios (RR), justifications of margin selection and estimated sample size. We evaluated the establishment of non-inferiority by examining whether the upper bound of estimated confidence interval (CI) exceeded the pre-specified non-inferiority margin.

\section{Statistical analysis}

We performed descriptive analysis for the extracted general characteristics. In particular, categorical variables were expressed as frequencies, while median and interquartile range (IQR) were used for continuous variables. We performed Pearson's Chi-square $\left(\chi^{2}\right)$ tests and MannWhitney $\mathrm{U}$ tests to compare the differences of distribution patterns of categorical and continuous characteristics, respectively, between trials with and without establishing 
non-inferiority. A 2 -sided $\mathrm{P}$ value $<0.05$ was considered as an indicator for significant association between a certain factor and establishment of non-inferiority. Since the probability of establishing non-inferiority should theoretically only be dependent on the type II error $(\beta)$ under the alternative hypothesis, any other external factors associated with establishment of non-inferiority would imply potential bias. Notably, to model the effect of noninferiority margin on reported outcome of non-inferiority, we first transformed margins expressed as rate difference to RRs based on the baseline outcome event rate. With regard to studies using continuous effect estimates such as mean differences as the primary outcome, we standardized the effect estimates with the reported standard deviations (SD), and then transformed the continuous estimates to ORs following the Hasselblad and Hedges' method $(11,12)$. A previous study had shown that HRs, ORs, and RRs can be good numerical approximations of one another (13). Therefore, we took the coefficient scale of log-transformed relative effects (HRs, RRs, and ORs) and investigated their association with ultimate establishment of non-inferiority.

All statistical analyses were performed using $\mathrm{R}$ (version 4.0.2; https://www.R-project.org/).

\section{Results}

\section{Selection of studies}

A total of 3,312 records were retrieved from the aforementioned three databases. After reviewing titles and abstracts, 746 records were identified for in-depth full-text review. Through cross-checking the trial registry identifier and reference of eligible studies, we enrolled 3 additional studies. At last, 347 non-inferiority surgical clinical trials were included in our study. The flow chart of study selection is presented in Figure 1.

\section{General trial characteristics}

Basic characteristics of the 347 eligible trials are shown in Table 1, with detailed information available in Table S2. Among all the trials, 277 (79.8\%) claimed non-inferiority in conclusion. As for methodologic parameters, not much diversity was observed in terms of type I (median 0.05 , IQR 0.025-0.05) and type II error (median 0.20, IQR 0.10-0.20); the median sample size was 261 with IQR between 136 and 800; the majority of non-inferiority margins in HR were less than 2 and with a median number of 1.46 (IQR
1.23-2.00). Only 99 (28.5\%) trials reported justification for the margin and $58(58.6 \%)$ of them were based on previous trials, while $19(19.2 \%)$ used effect retention method and 16 (16.2\%) relied on expert consensus. A total of 204 (58.8\%) trials reported method for sample size calculation; of them, $187(91.7 \%)$ were based on previous trials, and only 15 (7.4\%) followed instructions from methodologic studies.

\section{Quantitative analysis}

As presented in Table 2, the essential characteristics were compared between trials with or without establishment of non-inferiority. Among all surgical specialties, cardiovascular related interventions were performed in 157 $(56.7 \%)$ trials that claimed non-inferiority and 29 (41.4\%) trials that failed, which were the highest in both groups. The distribution of surgical specialties was not significantly associated with the establishment of non-inferiority $(\mathrm{P}=0.09)$. In trials that achieved non-inferiority, a lower percentage of published protocols (15.9\% vs. $22.9 \%)$ and lower journal impact factor (6.38 vs. 8.43) were observed, although no significant difference was detected. A significant association was found between industry funding and increased odds of achieving non-inferiority (OR: 1.17, 95\% CI: 1.06 to $1.30, \mathrm{P}=0.001)$. In addition, trials that presented their findings in conferences were significantly less likely to establish non-inferiority (OR: 0.83, 95\% CI: 0.69 to 0.99 , $\mathrm{P}=0.035)$. Regarding parameters associated with trial design, only $13(3.7 \%)$ trials reported the pre-specified margin in registration, and $99(28.5 \%)$ trials justified their selection of non-inferiority margin. No significant associations were identified between the established non-inferiority and other parameters including type I error, type II error, noninferiority margin, and sample size.

\section{Discussion}

Multiple studies have investigated the design, conduct, and interpretation of surgical non-inferiority trials and highlighted the deficiencies such as arbitrary selection of margin and poor quality of reporting $(14,15)$. These studies, however, have only focused on a subspecialty, such as surgical oncology, and were therefore limited by small number of included trials. Therefore, we performed a systematic bibliometric analysis which summarized 347 previously published non-inferiority phase II and III surgical trials.

To our best knowledge, this is the first effort that 


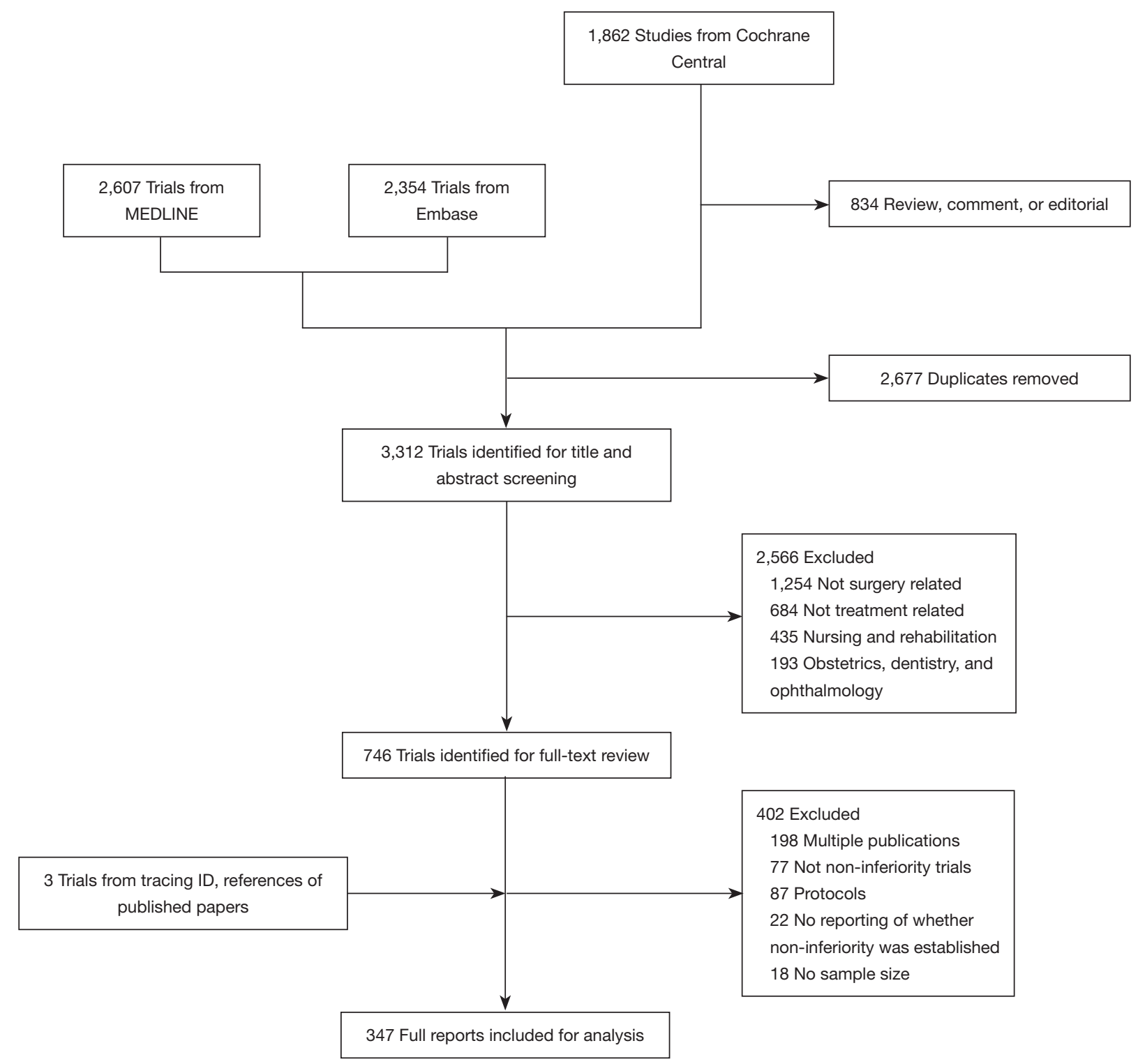

Figure 1 Flow diagram of study selection process.

quantitatively assessed factors associated with findings of published non-inferiority trials in surgery. We identified industry funding and conference presentation as potential sources of bias in surgical non-inferiority trials. We detected significant industry sponsorship bias which led to the excess establishment of non-inferiority in existing surgical clinical trials, resonating with a previous systematic review which included trials from all disciplines and found that industry-funded trials were more likely to use noninferiority designs and report "favorable" results (16). To improve transparent reporting, funding sources should be clearly reported both in the trial registration record and the ultimate publication. If an industry-funded trial chooses a product from competing companies as the control arm, a specified statement should be added as part of the competing of interests. We also found that underreporting of trial design and trial results prior to the ultimate publication of trial findings was associated with higher probability of concluding non-inferiority. Based on our findings, conference presentations should be encouraged as it might help preventing possible post-hoc distortion to the original study design. In addition to these biases, 
Table 1 Summary of essential characteristics of the 347 included non-inferiority trials

\begin{tabular}{|c|c|}
\hline Characteristics & Number (\%) \\
\hline \multicolumn{2}{|l|}{ Trial status } \\
\hline Full report & 347 \\
\hline Completed & $331(95.4)$ \\
\hline Interim & $2(0.6)$ \\
\hline Terminated & $14(4.0)$ \\
\hline \multicolumn{2}{|l|}{ Publication year } \\
\hline 2016-2020 & $175(50.4)$ \\
\hline $2011-2015$ & $131(37.8)$ \\
\hline 2006-2010 & $37(10.7)$ \\
\hline 2003-2005 & $4(1.1)$ \\
\hline \multicolumn{2}{|l|}{ Country } \\
\hline Europe & $159(45.8)$ \\
\hline Asia & $93(26.8)$ \\
\hline North America & $87(25.1)$ \\
\hline Others & $8(2.3)$ \\
\hline \multicolumn{2}{|l|}{ Multi-center trials } \\
\hline Yes & $297(85.6)$ \\
\hline No & $50(14.4)$ \\
\hline \multicolumn{2}{|l|}{ Trial registered } \\
\hline Yes & $287(82.7)$ \\
\hline No & $60(17.3)$ \\
\hline \multicolumn{2}{|l|}{ Registry institution } \\
\hline Clinical trial.gov & 237 (82.6) \\
\hline UMIN & $12(4.2)$ \\
\hline NTR & $12(4.2)$ \\
\hline ISRCTN & $10(3.5)$ \\
\hline ChiCTR & $5(1.7)$ \\
\hline Others & $11(3.8)$ \\
\hline \multicolumn{2}{|l|}{ Type of comparison } \\
\hline Surgery vs. surgery & $325(93.7)$ \\
\hline Surgery vs. medication & $22(6.3)$ \\
\hline \multicolumn{2}{|c|}{$\begin{array}{l}\text { Comparison between different procedures } \\
\text { (surgery vs. surgery) }\end{array}$} \\
\hline Stent vs. stent & $119(36.6)$ \\
\hline Open surgery vs. open surgery & $102(31.4)$ \\
\hline Intervention vs. intervention & $71(21.8)$ \\
\hline Open surgery vs. intervention & $33(10.2)$ \\
\hline
\end{tabular}

Table 1 (continued)
Table 1 (continued)

\begin{tabular}{lc}
\hline Characteristics & Number (\%) \\
\hline Primary endpoint & \\
Survival & $120(34.6)$ \\
Event free survival & $21(6.1)$ \\
Overall survival & $14(4.0)$ \\
Recurrence free survival & $7(2.0)$ \\
Disease free survival & \\
Surgical success & $86(24.8)$ \\
Success rate & \\
Continuous & $51(14.7)$ \\
Late luminal loss & $26(7.5)$ \\
Score or index & $22(6.3)$ \\
Others &
\end{tabular}

UMIN, University Hospital Medical Information Network; NTR, Netherlands Trial Registry; ISRCTN, International Standard Randomized Controlled Trial Number Register; ChiCTR, Chinese Clinical Trial Register.

it is worth noting that our study focuses on randomized controlled trials, which may have limited generalizability. Non-inferiority achieved by existing surgical trials should be further validated in the real-world settings due to potentially diverse population (17).

In our study, we found that methodological details of non-inferiority design were severely underreported in current surgical trials. For example, among the 347 eligible trials, only 99 (28.5\%) justified their selection of noninferiority margin, which is comparable to a prior study including trials from all disciplines (6). Poorly justified margin specification could lead to excess achievement of non-inferiority; although in our study, the transformed margin was not associated with establishment of noninferiority $(\mathrm{P}=0.81)$. We thereby call for compulsory reporting of non-inferiority margin and margin justification details in trial registry such as Clinicaltrials.gov and published articles. Any protocol amendment should be documented in detail with caution.

Although no association was observed between surgical specialty and establishment of non-inferiority in our study, potential bias could have been generated, which merits further investigation. In particular, among all included trials of our study, $186(53.6 \%)$ trials investigated cardiovascular and peripheral vascular surgeries, and $57(16 \%)$ trials investigated general surgeries. A prior cross-sectional 
Table 2 Characteristics of 347 trials with or without establishment of non-inferiority

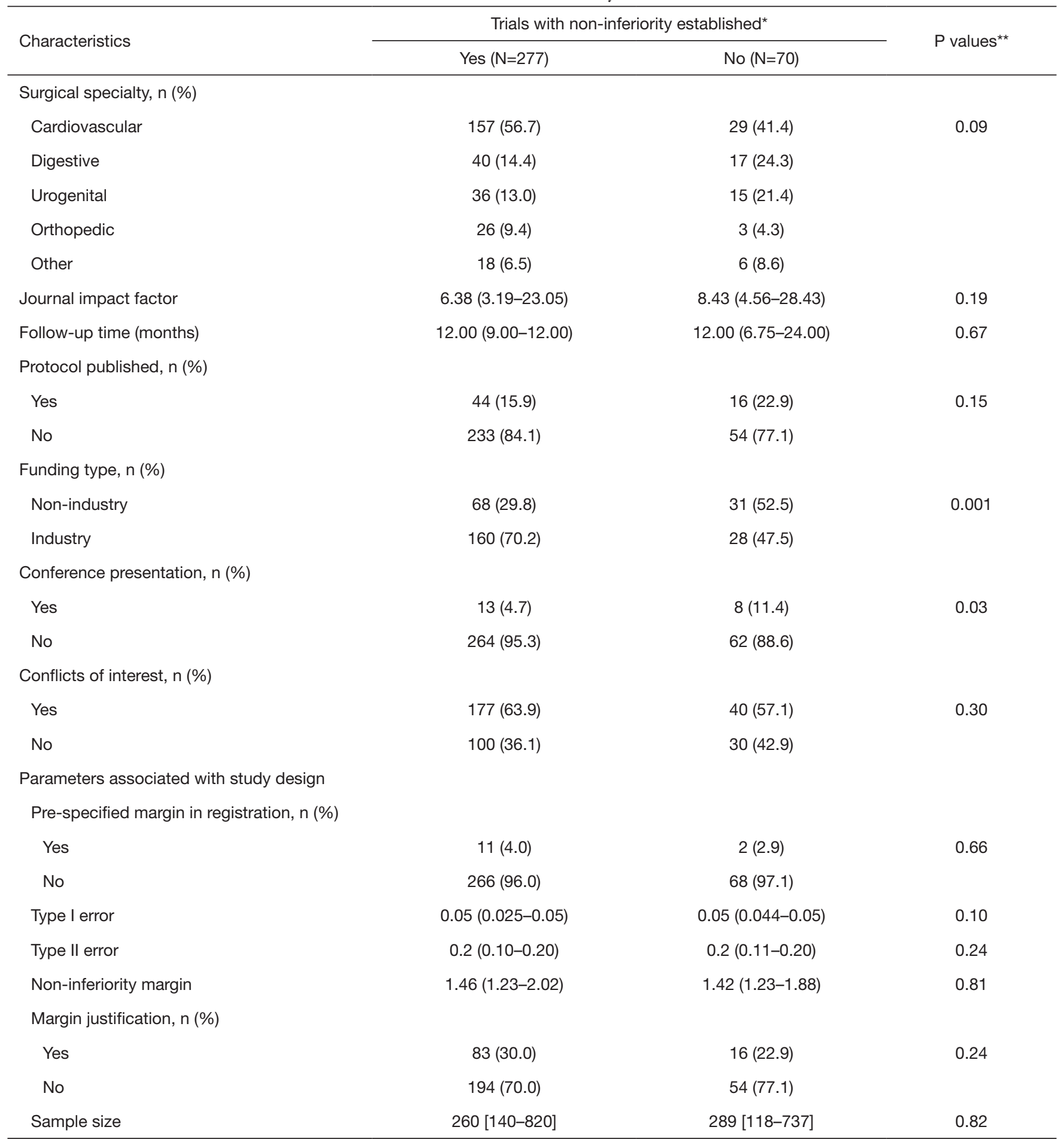

${ }^{*}$, medians and quartiles were used for continuous variables; ${ }^{* *}, \mathrm{P}$ values for chi-square tests except for follow-up time where a MannWhitney $U$ test was used. 
survey focusing on all types of surgical trials reported that general surgery accounted for the largest proportion (34.5\%) of all published surgical trials (10). Our findings indicated that non-inferiority design might be more commonly adopted in trials of cardiovascular surgeries. In our study, $119(34.3 \%)$ trials focused on comparisons across different types of coronary stents. Whether these trials adopted noninferiority design in order to chase higher probability of achieving favorable outcomes, and what role funders played in selecting this type of study design remain unclear, and therefore are yet to be explored in-depth by future research.

The main limitation of our study is that we only enrolled published trials which were indexed in databases such as MEDLINE, Embase, and Cochrane Central which led to omission of unpublished data.

In summary, we systematically analyzed previously published non-inferiority trials in surgery and identified potential biases in such type of trials. Based on our findings, future trials should continue to improve transparent reporting of potential conflicts of interests especially the funding sources. In addition, trials are encouraged to be presented in conferences to increase visibility and to some extent prevent post-hoc manipulation of the study design. Last but not the least, trials should be registered with full details of study design in registries such as Clinicaltrials.gov, or publish these details in the protocol.

\section{Acknowledgments}

We thank Dr. Xia Shen for providing consultations to the statistical analysis, and as well as Dr. Thomas Forbes for the clinical guidance.

Funding: None.

\section{Footnote}

Reporting Checklist: The authors have completed the PRISMA reporting checklist. Available at https://dx.doi. org/10.21037/atm-21-2626

Conflicts of Interest: All authors have completed the ICMJE uniform disclosure form (available at https://dx.doi. org/10.21037/atm-21-2626). The authors have no conflicts of interest to declare.

Ethical Statement: The authors are accountable for all aspects of the work in ensuring that questions related to the accuracy or integrity of any part of the work are appropriately investigated and resolved.

Open Access Statement: This is an Open Access article distributed in accordance with the Creative Commons Attribution-NonCommercial-NoDerivs 4.0 International License (CC BY-NC-ND 4.0), which permits the noncommercial replication and distribution of the article with the strict proviso that no changes or edits are made and the original work is properly cited (including links to both the formal publication through the relevant DOI and the license). See: https://creativecommons.org/licenses/by-nc-nd/4.0/.

\section{References}

1. Mulla SM, Scott IA, Jackevicius CA, et al. How to use a noninferiority trial: users' guides to the medical literature. JAMA 2012;308:2605-11.

2. Merseburger AS, Herrmann TR, Shariat SF, et al. EAU guidelines on robotic and single-site surgery in urology. Eur Urol 2013;64:277-91.

3. Zerey M, Hawver LM, Awad Z, et al. SAGES evidencebased guidelines for the laparoscopic resection of curable colon and rectal cancer. Surg Endosc 2013;27:1-10.

4. Middleton LJ. Falling in the margin: Randomised controlled trials with a non-inferiority design. BJOG 2021. [Epub ahead of print]. doi: 10.1111/1471-0528.16702.

5. Burotto M, Prasad V, Fojo T. Non-inferiority trials: why oncologists must remain wary. Lancet Oncol 2015;16:364-6.

6. Gopal AD, Desai NR, Tse T, et al. Reporting of noninferiority trials in ClinicalTrials.gov and corresponding publications. JAMA 2015;313:1163-5.

7. Mauri L, D'Agostino RB Sr. Challenges in the Design and Interpretation of Noninferiority Trials. N Engl J Med 2017;377:1357-67.

8. Rehal S, Morris TP, Fielding K, et al. Non-inferiority trials: are they inferior? A systematic review of reporting in major medical journals. BMJ Open 2016;6:e012594.

9. Surgical Procedures, Operative. National Center for Biotechnology Information. Available online: https:// www.ncbi.nlm.nih.gov/mesh/68013514. (Accessed in April 2020). 2020.

10. Yu J, Chen W, Chen S, et al. Design, Conduct, and Analysis of Surgical Randomized Controlled Trials: A Cross-sectional Survey. Ann Surg 2019;270:1065-9.

11. da Costa BR, Rutjes AW, Johnston BC, et al. Methods to convert continuous outcomes into odds ratios of treatment response and numbers needed to treat: metaepidemiological study. Int J Epidemiol 2012;41:1445-59. 
12. Hasselblad V, Hedges LV. Meta-analysis of screening and diagnostic tests. Psychol Bull 1995;117:167-78.

13. Symons MJ, Moore DT. Hazard rate ratio and prospective epidemiological studies. J Clin Epidemiol 2002;55:893-9.

14. Parsyan A, Marini W, Fazelzad R, et al. Current Issues in Conduct and Reporting of Noninferiority Randomized Controlled Trials in Surgical Management of Cancer Patients. Ann Surg Oncol 2021;28:39-47.

15. Blencowe NS, Chana P, Whistance RN, et al. Outcome reporting in neoadjuvant surgical trials: a systematic review

Cite this article as: Shu C, Huang B, Yuan D, Yang Y, Du X, He Y, Chen X, Zhao J. Surgical clinical trials with noninferiority design: a cross-sectional bibliometric analysis. Ann Transl Med 2021;9(16):1302. doi: 10.21037/atm-21-2626 of the literature and proposals for new standards. J Natl Cancer Inst 2014;106:dju217.

16. Flacco ME, Manzoli L, Boccia S, et al. Head-to-head randomized trials are mostly industry sponsored and almost always favor the industry sponsor. J Clin Epidemiol 2015;68:811-20.

17. Zhou YL, Zhang YG, Zhang R, et al. Population diversity of cardiovascular outcome trials and real-world patients with diabetes in a Chinese tertiary hospital. Chin Med J (Engl) 2021;134:1317-23. 


\section{Supplementary}

Table S1 Search strategies for MEDLINE, Embase, and Cochrane Central Register of Controlled Trials

Database: MEDLINE (Limited to human studies)

Surgical Procedures, Operative.mp. or exp Surgical Procedures, Operative/or Specialties, Surgical.mp. or exp Specialties, Surgical/ or surgery.mp. or Minimally Invasive Surgical Procedures.mp. or exp Minimally Invasive Surgical Procedures/or (Surgery or Surgeries or Surgerys or Surgical or Operative or Perioperative or Intraoperative or Postoperative or Intervention* or Invasive).af.

AND

Noninferiority.mp. or Non inferiority.mp. or (Non-inferiority or Noninferiority or Non-inferior or Noninferior).af.

AND

Clinical trial.mp. or exp Clinical Trial/or Randomized Controlled Trial.mp. or exp Randomized Controlled Trial/or Trial.mp. or Trial.af.

Database: Embase (Limited to human studies)

exp Surgery/or Surgery.mp. or Surgical technique.mp. or exp Surgical technique/or Surgical technology.mp. or exp Surgical technology/ or Surgical.mp. or Minimally invasive surgery.mp. or exp Minimally invasive surgery/or (Surgery or Surgeries or Surgeries or Surgical or Operative or Perioperative or Intraoperative or Postoperative or Intervention* or Invasive).af.

AND

Noninferiority.mp. or Non inferiority.mp. or (Non-inferiority or Noninferiority or Non-inferior or Noninferior).af.

AND

Clinical trial.mp. or exp Clinical trial/or Non-inferiority trial.mp. or exp Non-inferiority trial/or Randomized controlled trial.mp. or exp Randomized controlled trial/or Trial.mp. or Trial.af.

Database: Cochrane Central Register of Controlled Trials (Words variations were searched)

(“Surgery"):ti,ab,kw OR (“noninferiority”):ti,ab,kw 
差 


\section{References}

1. Schiele F, Meneveau N, Gilard M, et al. Intravascular ultrasound-guided balloon angioplasty compared with stent: Immediate and 6-month results of the multicenter, randomized Balloon Equivalent to Stent study (BEST). Circulation 2003;107:545-51.

2. Nelson H, Sargent DJ, Wieand HS, et al. A Comparison of Laparoscopically Assisted and Open Colectomy for Colon Cancer. New England Journal of Medicine 2004;350:2050-9+114.

3. Yadav JS, Wholey MH, Kuntz RE, et al. Protected carotidartery stenting versus endarterectomy in high-risk patients. New England Journal of Medicine 2004;351:1493$501+586$.

4. Dibra A, Kastrati A, Mehilli J, et al. Paclitaxel-eluting or sirolimus-eluting stents to prevent restenosis in diabetic patients. New England Journal of Medicine 2005;353:66370.

5. Hacke W. 30 day results from the SPACE trial of stentprotected angioplasty versus carotid endarterectomy in symptomatic patients: a randomised non-inferiority trial. Lancet 2006;368:1239-47.

6. Kitchener HC, Dunn G, Lawton V, et al. Laparoscopic versus open colposuspension--results of a prospective randomised controlled trial. BJOG: An International Journal of Obstetrics \& Gynaecology 2006;113:1007-13.

7. Mas JL, Chatellier G, Beyssen B, et al. Endarterectomy versus stenting in patients with symptomatic severe carotid stenosis. New England Journal of Medicine 2006;355:1660-71.

8. Mehilli J, Dibra A, Kastrati A, et al. Randomized trial of paclitaxel- and sirolimus-eluting stents in small coronary vessels. European Heart Journal 2006;27:260-6.

9. Mehilli J, Kastrati A, Wessely R, et al. Randomized trial of a nonpolymer-based rapamycin-eluting stent versus a polymer-based paclitaxel-eluting stent for the reduction of late lumen loss. Circulation 2006;113:273-9.

10. Wright D, Gobin JP, Bradbury AW, et al. Varisolve polidocanol microfoam compared with surgery or sclerotherapy in the management of varicose veins in the presence of trunk vein incompetence: European randomized controlled trial. Phlebology 2006;21:180-90.

11. Turco MA, Ormiston JA, Popma JJ, et al. Polymer-Based, Paclitaxel-Eluting TAXUS Liberte Stent in De Novo Lesions. The Pivotal TAXUS ATLAS Trial. Journal of the American College of Cardiology 2007;49:1676-83.

12. Barber MD, Kleeman S, Karram MM, et al.
Transobturator tape compared with tension-free vaginal tape for the treatment of stress urinary incontinence: A randomized controlled trial. Obstetrics and Gynecology 2008;111:611-21.

13. Chevalier B, Di Mario C, Neumann FJ, et al. A Randomized, Controlled, Multicenter Trial to Evaluate the Safety and Efficacy of Zotarolimus- Versus PaclitaxelEluting Stents in De Novo Occlusive Lesions in Coronary Arteries. The ZoMaxx I Trial. JACC: Cardiovascular Interventions 2008;1:524-32.

14. Krucoff MW, Kereiakes DJ, Petersen JL, et al. A Novel Bioresorbable Polymer Paclitaxel-Eluting Stent for the Treatment of Single and Multivessel Coronary Disease. Primary Results of the COSTAR (Cobalt Chromium Stent With Antiproliferative for Restenosis) II Study. Journal of the American College of Cardiology 2008;51:1543-52.

15. Ormiston JA, Mahmud E, Turco MA, et al. Direct Stenting With the TAXUS Liberte Drug-Eluting Stent. Results From the TAXUS ATLAS DIRECT STENT Study. JACC: Cardiovascular Interventions 2008;1:150-60.

16. Stone GW, Midei M, Newman W, et al. Comparison of an everolimus-eluting stent and a paclitaxel-eluting stent in patients with coronary artery disease: A randomized trial. JAMA - Journal of the American Medical Association 2008;299:1903-13.

17. Szeimies RM, Ibbotson S, Murrell DF, et al. A clinical study comparing methyl aminolevulinate photodynamic therapy and surgery in small superficial basal cell carcinoma (8-20 mm), with a 12-month follow-up. Journal of the European Academy of Dermatology and Venereology 2008;22:1302-11.

18. Turco MA, Ormiston JA, Popma JJ, et al. Reduced Risk of Restenosis in Small Vessels and Reduced Risk of Myocardial Infarction in Long Lesions With the New Thin-Strut TAXUS Liberte Stent. 1-Year Results From the TAXUS ATLAS Program. JACC: Cardiovascular Interventions 2008;1:699-709.

19. Windecker S, Serruys PW, Wandel S, et al. Biolimuseluting stent with biodegradable polymer versus sirolimus-eluting stent with durable polymer for coronary revascularisation (LEADERS): a randomised noninferiority trial. The Lancet 2008;372:1163-73.

20. Bonjer. Survival after laparoscopic surgery versus open surgery for colon cancer: long-term outcome of a randomised clinical trial. The Lancet Oncology 2009;10:44-52.

21. Byrne RA, Kastrati A, Kufner S, et al. Randomized, noninferiority trial of three limus agent-eluting stents with 
different polymer coatings: The Intracoronary Stenting and Angiographic Results: Test Efficacy of 3 LimusEluting Stents (ISAR-TEST-4) Trial. European Heart Journal 2009;30:2441-9.

22. Chevalier B, Silber S, Park SJ, et al. Randomized comparison of the Nobori Biolimus A9-eluting coronary stent with the Taxus Liberte paclitaxel-eluting coronary stent in patients with stenosis in native coronary arteries: the NOBORI 1 trial--Phase 2. Circulation: Cardiovascular Interventions 2009;2:188-95.

23. Holmes DR, Reddy VY, Turi ZG, et al. Percutaneous closure of the left atrial appendage versus warfarin therapy for prevention of stroke in patients with atrial fibrillation: a randomised non-inferiority trial. The Lancet 2009;374:534-42.

24. Murrey D, Janssen M, Delamarter R, et al. Results of the prospective, randomized, controlled multicenter Food and Drug Administration investigational device exemption study of the ProDisc-C total disc replacement versus anterior discectomy and fusion for the treatment of 1-level symptomatic cervical disc disease. Spine Journal 2009;9:275-86.

25. Puskas JD, Halkos ME, Balkhy H, et al. Evaluation of the PAS-Port Proximal Anastomosis System in coronary artery bypass surgery (the EPIC trial). Journal of Thoracic and Cardiovascular Surgery 2009;138:125-32.

26. Saltzman CL, Mann RA, Ahrens JE, et al. Prospective controlled trial of STAR total ankle replacement versus ankle fusion: Initial results. Foot and Ankle International 2009;30:579-96.

27. Serruvs PW, Morice MC, Kappetein AP, et al.

Percutaneous coronary intervention versus coronary-artery bypass grafting for severe coronary artery disease. New England Journal of Medicine 2009;360:961-72.

28. Thiele H, Neumann-Schniedewind P, Jacobs S, et al. Randomized Comparison of Minimally Invasive Direct Coronary Artery Bypass Surgery Versus Sirolimus-Eluting Stenting in Isolated Proximal Left Anterior Descending Coronary Artery Stenosis. Journal of the American College of Cardiology 2009;53:2324-31.

29. Verheye S, Agostoni P, Dawkins KD, et al. The GENESIS (Randomized, Multicenter Study of the PimecrolimusEluting and Pimecrolimus/Paclitaxel-Eluting Coronary Stent System in Patients with De Novo Lesions of the Native Coronary Arteries) Trial. JACC: Cardiovascular Interventions 2009;2:205-14.

30. Cortese B, Micheli A, Picchi A, et al. Paclitaxel-coated balloon versus drug-eluting stent during PCI of small coronary vessels, a prospective randomised clinical trial. The PICCOLETO study. Heart 2010;96:1291-6.

31. Darai E, Dubernard G, Coutant C, et al. Randomized trial of laparoscopically assisted versus open colorectal resection for endometriosis: morbidity, symptoms, quality of life, and fertility. Annals of Surgery 2010;251:1018-23.

32. Kapur A, Hall RJ, Malik IS, et al. Randomized Comparison of Percutaneous Coronary Intervention With Coronary Artery Bypass Grafting in Diabetic Patients. 1-Year Results of the CARDia (Coronary Artery Revascularization in Diabetes) Trial. Journal of the American College of Cardiology 2010;55:432-40.

33. Kereiakes DJ, Cannon LA, Feldman RL, et al. Clinical and angiographic outcomes after treatment of de novo coronary stenoses with a novel platinum chromium thinstrut stent: primary results of the PERSEUS (Prospective Evaluation in a Randomized Trial of the Safety and Efficacy of the Use of the TAXUS Element PaclitaxelEluting Coronary Stent System) trial. J Am Coll Cardiol 2010;56:264-71.

34. Leon MB, Mauri L, Popma JJ, et al. A Randomized Comparison of the Endeavor Zotarolimus-Eluting Stent Versus the TAXUS Paclitaxel-Eluting Stent in De Novo Native Coronary Lesions. 12-Month Outcomes From the ENDEAVOR IV Trial. Journal of the American College of Cardiology 2010;55:543-54.

35. Nix J, Smith A, Kurpad R, et al. Prospective randomized controlled trial of robotic versus open radical cystectomy for bladder cancer: perioperative and pathologic results. European Urology 2010;57:196-201.

36. Ormiston JA, Abizaid A, Spertus J, et al. Six-month results of the NEVO res-elution I (NEVO RES-I) Trial : A randomized, multicenter comparison of the nevo sirolimus-eluting coronary stent with the taxus liberte paclitaxel-eluting stent in de novo native coronary artery lesions. Circulation: Cardiovascular Interventions 2010;3:556-64.

37. Park DW, Kim YH, Yun SC, et al. Comparison of zotarolimus-eluting stents with sirolimus- and paclitaxeleluting stents for coronary revascularization: The ZEST (Comparison of the Efficacy and Safety of ZotarolimusEluting Stent with Sirolimus-Eluting and PacliTaxelEluting Stent for Coronary Lesions) randomized trial. Journal of the American College of Cardiology 2010;56:1187-95.

38. Serruys PW, Silber S, Garg S, et al. Comparison of zotarolimus-eluting and everolimus-eluting coronary stents. New England Journal of Medicine 
2010;363:136-46.

39. Serruys PW, Garg S, Abizaid A, et al. A randomised comparison of novolimus-eluting and zotarolimuseluting coronary stents: 9-Month follow-up results of the EXCELLA II study. EuroIntervention 2010;6:195-205.

40. Stone GW, Rizvi A, Newman W, et al. EverolimusEluting versus Paclitaxel-Eluting Stents in Coronary Artery Disease. New England Journal of Medicine 2010;362:1663-74.

41. Vergote I, Trope CG, Amant F, et al. Neoadjuvant chemotherapy or primary surgery in stage IIIC or IV ovarian cancer. New England Journal of Medicine 2010;363:943-53.

42. Amat i Tardiu L, Franco EM, Vicens JML. ContasureNeedleless compared with transobturator-TVT for the treatment of stress urinary incontinence. International Urogynecology Journal 2011;22:827-33.

43. Boudriot E, Thiele H, Walther T, et al. Randomized comparison of percutaneous coronary intervention with sirolimus-eluting stents versus coronary artery bypass grafting in unprotected left main stem stenosis. Journal of the American College of Cardiology 2011;57:538-45.

44. Delamarter R, Zigler JE, Balderston RA, et al. Prospective, randomized, multicenter food and drug administration investigational device exemption study of the ProDisc-L total disc replacement compared with circumferential arthrodesis for the treatment of two-level lumbar degenerative disc disease: Results at twenty-four months. Journal of Bone and Joint Surgery - Series A 2011;93:705-15.

45. Elit L, Levine MN, Julian JA, et al. Expectant management versus immediate treatment for low-grade cervical intraepithelial neoplasia : a randomized trial in Canada and Brazil. Cancer 2011;117:1438-45.

46. Giuliano AE, Hunt KK, Ballman KV, et al. Axillary dissection vs no axillary dissection in women with invasive breast cancer and sentinel node metastasis: A randomized clinical trial. JAMA - Journal of the American Medical Association 2011;305:569-75.

47. Klomp M, Beijk MA, Varma C, et al. 1-Year outcome of TRIAS HR (TRI-stent Adjudication Study-High Risk of restenosis): A multicenter, randomized trial comparing genous endothelial progenitor cell capturing stents with drug-eluting stents. JACC: Cardiovascular Interventions 2011;4:896-904.

48. Lee CW, Park DW, Seung KB, et al. Comparison of dual drug-eluting Cilotax stent and paclitaxel-eluting Taxus Liberte stent in native coronary artery lesions. American
Journal of Cardiology 2011;107:990-4.

49. Massberg S, Byrne RA, Kastrati A, et al. Polymer-free sirolimus- and probucol-eluting versus new generation zotarolimus-eluting stents in coronary artery disease: The Intracoronary stenting and angiographic results: Test efficacy of sirolimus- and probucol-eluting versus zotarolimus-eluting stents (ISAR-TEST 5) Trial. Circulation 2011;124:624-32.

50. Park SJ, Kim YH, Park DW, et al. Randomized trial of stents versus bypass surgery for left main coronary artery disease. New England Journal of Medicine 2011;364:1718-27.

51. Park KW, Chae IH, Lim DS, et al. Everolimus-eluting versus sirolimus-eluting stents in patients undergoing percutaneous coronary intervention: The excellent (efficacy of Xience/Promus versus cypher to reduce late loss after stenting) randomized trial. Journal of the American College of Cardiology 2011;58:1844-54.

52. Park DW, Kim YH, Song HG, et al. Comparison of everolimus- and sirolimus-eluting stents in patients with long coronary artery lesions: A randomized LONG-DESIII (Percutaneous Treatment of LONG Native Coronary Lesions with Drug-Eluting Stent-III) trial. JACC: Cardiovascular Interventions 2011;4:1096-103.

53. Pilgrim T, Raber L, Limacher A, et al. Comparison of titanium-nitride-oxide-coated stents with zotarolimuseluting stents for coronary revascularization a randomized controlled trial. Jacc: Cardiovascular Interventions 2011;4:672-82.

54. Roos DE, Smith JG, Stephens SW. Radiosurgery versus Surgery, both with Adjuvant Whole Brain Radiotherapy, for Solitary Brain Metastases: A Randomised Controlled Trial. Clinical Oncology 2011;23:646-51.

55. Smith CR, Leon MB, Mack MJ, et al. Transcatheter versus surgical aortic-valve replacement in high-risk patients. New England Journal of Medicine 2011;364:2187-98.

56. Stone GW, Teirstein PS, Meredith IT, et al. A prospective, randomized evaluation of a novel everolimus-eluting coronary stent: The PLATINUM (a prospective, randomized, multicenter trial to assess an everolimuseluting coronary stent system [PROMUS element] for the treatment of up to two de novo coronary artery lesions) trial. Journal of the American College of Cardiology 2011;57:1700-8.

57. Van Poppel H, Da Pozzo L, Albrecht W, et al. A prospective, randomised EORTC intergroup phase 3 study comparing the oncologic outcome of elective nephronsparing surgery and radical nephrectomy for low-stage 
renal cell carcinoma. European Urology 2011;59:543-52.

58. Vons C, Barry C, Maitre S, et al. Amoxicillin plus clavulanic acid versus appendicectomy for treatment of acute uncomplicated appendicitis: An open-label, noninferiority, randomised controlled trial. The Lancet 2011;377:1573-9.

59. Worthington-Kirsch RL, Siskin GP, Hegener P, et al. Comparison of the efficacy of the embolic agents acrylamido polyvinyl alcohol microspheres and tris-acryl gelatin microspheres for uterine artery embolization for leiomyomas: A prospective randomized controlled trial. CardioVascular and Interventional Radiology 2011;34:493-501.

60. Xu B, Dou KF, Han YL, et al. A prospective multicenter parallel-controlled trial of TIVOLI biodegradablepolymer-based sirolimus-eluting stent compared to ENDEAVOR zotarolimus-eluting stent for the treatment of coronary artery disease: 8-month angiographic and 2-year clinical follow-up results. Chinese Medical Journal 2011;124:811-6.

61. Yeung AC, Leon MB, Jain A, et al. Clinical evaluation of the resolute zotarolimus-eluting coronary stent system in the treatment of de novo lesions in native coronary arteries: The RESOLUTE US clinical trial. Journal of the American College of Cardiology 2011;57:1778-83.

62. Ahn JM, Park DW, Kim YH, et al. Comparison of resolute zotarolimus-eluting stents and sirolimus-eluting stents in patients with de novo long coronary artery lesions a randomized LONG-DES IV trial. Circulation: Cardiovascular Interventions 2012;5:633-40.

63. Bae H, Hatten HP, Jr., Linovitz R, et al. A prospective randomized FDA-IDE trial comparing Cortoss with PMMA for vertebroplasty: a comparative effectiveness research study with 24-month follow-up. Spine 2012;37:544-50.

64. Barber MD, Weidner AC, Sokol AI, et al. Singleincision mini-sling compared with tension-free vaginal tape for the treatment of stress urinary incontinence: A randomized controlled trial. Obstetrics and Gynecology 2012;119:328-37.

65. Carrie D, Berland J, Verheye S, et al. A Multicenter Randomized Trial Comparing Amphilimus- With Paclitaxel-Eluting Stents in De Novo Native Coronary Artery Lesions. Journal of the American College of Cardiology 2012.

66. Fairman RM, Tuchek JM, Lee WA, et al. Pivotal results for the medtronic valiant thoracic stent graft system in the VALOR II trial. Journal of Vascular Surgery 2012;56:1222- 31.e1.

67. Fujita J, Kurokawa Y, Sugimoto T, et al. Survival benefit of bursectomy in patients with resectable gastric cancer: interim analysis results of a randomized controlled trial. Gastric Cancer 2012;15:42-8.

68. Gray WA, Yeung AC, Cutlip DE, et al. A randomized, controlled, multi-center trial comparing the safety and efficacy of zotarolimus-eluting and paclitaxel-eluting stents in de novo lesions in coronary arteries: Final results of the ZoMaxx II trial. International Journal of Cardiology 2012;157:96-101.

69. Grube E, Chevalier B, Guagliumi G, et al. The SPIRIT $v$ Diabetic Study: A randomized clinical evaluation of the XIENCE $v$ everolimus-eluting stent vs the TAXUS Liberte paclitaxel-eluting stent in diabetic patients with de novo coronary artery lesions. American Heart Journal 2012;163:867-75.e1.

70. Hofma SH, Brouwer J, Velders MA, et al. Secondgeneration everolimus-eluting stents versus first-generation sirolimus-eluting stents in acute myocardial infarction: 1-year results of the randomized XAMI (XienceV Stent vs. Cypher Stent in Primary PCI for acute myocardial infarction) trial. Journal of the American College of Cardiology 2012;60:381-7.

71. Jang JW, Lee SS, Song TJ, et al. Endoscopic ultrasoundguided transmural and percutaneous transhepatic gallbladder drainage are comparable for acute cholecystitis. Gastroenterology 2012;142:805-11.

72. Jensen LO, Thayssen P, Hansen HS, et al. Randomized comparison of everolimus-eluting and sirolimus-eluting stents in patients treated with percutaneous coronary intervention: The Scandinavian Organization for Randomized Trials with Clinical Outcome IV (SORT OUT IV). Circulation 2012;125:1246-55.

73. Kadota K, Muramatsu T, Iwabuchi M, et al. Randomized comparison of the nobori biolimus A9-eluting stent with the sirolimus-eluting stent in patients with stenosis in native coronary arteries. Catheterization and Cardiovascular Interventions 2012;80:789-96.

74. Karjalainen PP, Niemela M, Airaksinen JKE, et al. A prospective randomised comparison of titanium-nitrideoxide-coated bioactive stents with everolimus-eluting stents in acute coronary syndrome: The BASE-ACS trial. EuroIntervention 2012;8:306-15.

75. Katsanos K, Karnabatidis D, Kitrou P, et al. Paclitaxelcoated balloon angioplasty vs. plain balloon dilation for the treatment of failing dialysis access: 6-Month interim results from a prospective randomized controlled trial. 
Journal of Endovascular Therapy 2012;19:263-72.

76. Kimura T, Morimoto T, Natsuaki M, et al. Comparison of everolimus-eluting and sirolimus-eluting coronary stents: 1-year outcomes from the randomized evaluation of sirolimus-eluting versus everolimus-eluting stent trial (RESET). Circulation 2012;126:1225-36.

77. Latib A, Colombo A, Castriota F, et al. A randomized multicenter study comparing a paclitaxel drugeluting balloon with a paclitaxel-eluting stent in small coronary vessels: The bello (balloon elution and late loss optimization) study. Journal of the American College of Cardiology 2012;60:2473-80.

78. Lefebvre JL, Andry G, Chevalier D, et al. Laryngeal preservation with induction chemotherapy for hypopharyngeal squamous cell carcinoma: 10-year results of EORTC trial 24891. Annals of Oncology 2012;23:2708-14.

79. Lukacs B, Loeffler J, Bruyre F, et al. Photoselective vaporization of the prostate with Greenlight 120-W laser compared with monopolar transurethral resection of the prostate: A multicenter randomized controlled trial. European Urology 2012;61:1165-73.

80. Meredith IT, Verheye S, Dubois CL, et al. Primary Endpoint Results of the EVOLVE Trial. A Randomized Evaluation of a Novel Bioabsorbable Polymer-Coated, Everolimus-Eluting Coronary Stent. Journal of the American College of Cardiology 2012.

81. Park HJ, Kim HY, Lee JM, et al. Randomized comparison of the efficacy and safety of zotarolimus-eluting stents vs. sirolimus-eluting stents for percutaneous coronary intervention in chronic total occlusion--CAtholic Total Occlusion Study (CATOS) trial. Circulation Journal 2012;76:868-75

82. Saver JL, Jahan R, Levy EI, et al. Solitaire flow restoration device versus the Merci Retriever in patients with acute ischaemic stroke (SWIFT): A randomised, parallel-group, non-inferiority trial. The Lancet 2012;380:1241-9.

83. Shadid N, Ceulen R, Nelemans P, et al. Randomized clinical trial of ultrasound-guided foam sclerotherapy versus surgery for the incompetent great saphenous vein. British Journal of Surgery 2012;99:1062-70.

84. von Birgelen C, Basalus MWZ, Tandjung K, et al. A Randomized Controlled Trial in Second-Generation Zotarolimus-Eluting Resolute Stents Versus EverolimusEluting Xience V Stents in Real-World Patients. The TWENTE Trial. Journal of the American College of Cardiology 2012.

85. Walker JL, Piedmonte MR, Spirtos NM, et al. Recurrence and survival after random assignment to laparoscopy versus laparotomy for comprehensive surgical staging of uterine cancer: Gynecologic Oncology Group LAP2 Study. Journal of Clinical Oncology 2012;30:695-700.

86. Xu B, Dou K, Yang Y, et al. Nine-month angiographic and 2-year clinical follow-up of the NOYA biodegradable polymer sirolimus-eluting stent in the treatment of patients with de novo native coronary artery lesions: The NOYA I trial. EuroIntervention 2012;8:796-802.

87. Yang $X$, Jiang $M$, Chen $X$, et al. TVT-O vs. TVT for the treatment of SUI: a non-inferiority study. International Urogynecology Journal 2012;23:99-104.

88. Yang X, Li H. A modified anterior compartment reconstruction and Prolift-a for the treatment of anterior pelvic organ prolapse: a non-inferiority study. Archives of Gynecology \& Obstetrics 2012;285:1593-7.

89. Zhang L, Yuan J, Liu G, et al. One-year clinical outcome of a randomized trial of polymer-free paclitaxel-eluting stents versus biodegradable polymer-based rapamycineluting stents in patients with coronary heart disease. Journal of Interventional Cardiology 2012;25:604-10.

90. Bastani H, Drca N, Insulander P, et al. Cryothermal vs. radiofrequency ablation as atrial flutter therapy: a randomized comparison. Europace 2013;15:420-8.

91. Bianchi-Ferraro AMHM, Bella ZIKJD, De ACR, et al. Single-incision sling compared with transobturator sling for treating stress urinary incontinence: A randomized controlled trial. International Urogynecology Journal 2013;24:1459-65.

92. Byrne RA, Neumann FJ, Mehilli J, et al. Paclitaxel-eluting balloons, paclitaxel-eluting stents, and balloon angioplasty in patients with restenosis after implantation of a drugeluting stent (ISAR-DESIRE 3): A randomised, open-label trial. The Lancet 2013;381:461-7.

93. Galimberti V, Cole BF, Zurrida S, et al. Axillary dissection versus no axillary dissection in patients with sentinel-node micrometastases (IBCSG 23-01): A phase 3 randomised controlled trial. The Lancet Oncology 2013;14:297-305.

94. Gao RL, Xu B, Lansky AJ, et al. A randomised comparison of a novel abluminal groove-filled biodegradable polymer sirolimus-eluting stent with a durable polymer everolimuseluting stent: Clinical and angiographic follow-up of the TARGET I trial. EuroIntervention 2013;9:75-83.

95. Hahalis G, Tsigkas G, Xanthopoulou I, et al. Transulnar compared with transradial artery approach as a default strategy for coronary procedures: A randomized trial: The transulnar or transradial instead of coronary transfemoral angiographies study (the AURA of ARTEMIS study). 
Circulation: Cardiovascular Interventions 2013;6:252-61.

96. Haude M, Lee SWL, Worthley SG, et al. The REMEDEE trial: A randomized comparison of a combination sirolimus-eluting endothelial progenitor cell capture stent with a paclitaxel-eluting stent. JACC: Cardiovascular Interventions 2013;6:334-43.

97. Jacobs AK, Normand SLT, Massaro JM, et al. Nonemergency PCI at hospitals with or without onsite cardiac surgery. New England Journal of Medicine 2013;368:1498-508.

98. Liistro F, Porto I, Angioli P, et al. Elutax paclitaxel-eluting balloon followed by bare-metal stent compared with Xience $\mathrm{v}$ drug-eluting stent in the treatment of de novo coronary stenosis: A randomized trial. American Heart Journal 2013;166:920-6.

99. Moreno R, Garcia E, Teles R, et al. Randomized comparison of sirolimus-eluting and everolimus-eluting coronary stents in the treatment of total coronary occlusions: results from the chronic coronary occlusion treated by everolimus-eluting stent randomized trial. Circulation: Cardiovascular Interventions 2013;6:21-8.

100. Natsuaki M, Kozuma K, Morimoto T, et al. Biodegradable polymer biolimus-eluting stent versus durable polymer everolimus-eluting stent: A randomized, controlled, noninferiority trial. Journal of the American College of Cardiology 2013;62:181-90.

101. Ribichini F, Romano M, Rosiello R, et al. A clinical and angiographic study of the XIENCE $\mathrm{V}$ everolimus-eluting coronary stent system in the treatment of patients with multivessel coronary artery disease: the EXECUTIVE trial (EXecutive RCT: evaluating XIENCE V in a multi vessel disease). JACC Cardiovasc Interv 2013;6:1012-22.

102. Rothmund R, Szyrach M, Reda A, et al. A prospective, randomized clinical comparison between UltraCision and the novel sealing and cutting device BiCision in patients with laparoscopic supracervical hysterectomy. Surgical Endoscopy 2013;27:3852-9.

103. Seo JB, Kang SH, Hur SH, et al. Randomized trial comparing the efficacy between different types of paclitaxel-eluting stents: The comparison of Efficacy between COroflex PLEASe and Taxus stent (ECOPLEASANT) randomized controlled trial. American Heart Journal 2013;165:733-43.

104. Smits PC, Hofma S, Togni M, et al. Abluminal biodegradable polymer biolimus-eluting stent versus durable polymer everolimus-eluting stent (COMPARE II): A randomised, controlled, non-inferiority trial. The Lancet 2013;381:651-60.
105.Sung JY, Baek JH, Kim KS, et al. Single-session treatment of benign cystic thyroid nodules with ethanol versus radiofrequency ablation: a prospective randomized study. Radiology 2013;269:293-300.

106. Tommaselli GA, D'Afiero A, Di Carlo C, et al. TensionFree Vaginal Tape-O and -Secur for the Treatment of Stress Urinary Incontinence: A Thirty-Six-Month Follow-Up Single-Blind, Double-Arm, Randomized Study. Journal of Minimally Invasive Gynecology 2013;20:198-204.

107. Van Vilsteren FGI, Phoa KN, Alvarez Herrero L, et al. A simplified regimen for focal radiofrequency ablation of Barrett's mucosa: A randomized multicenter trial comparing two ablation regimens. Gastrointestinal Endoscopy 2013;78:30-8.

108. Adams DH, Popma JJ, Reardon MJ, et al. Transcatheter aortic-valve replacement with a self-expanding prosthesis. New England Journal of Medicine 2014;370:1790-8.

109. Aigmuller T, Tammaa A, Tamussino K, et al. Retropubic vs. transobturator tension-free vaginal tape for female stress urinary incontinence: 3-Month results of a randomized controlled trial. International Urogynecology Journal and Pelvic Floor Dysfunction 2014;25:1023-30.

110. Atienza F, Almendral J, Ormaetxe JM, et al. Comparison of radiofrequency catheter ablation of drivers and circumferential pulmonary vein isolation in atrial fibrillation: A noninferiority randomized multicenter RADAR-AF trial. Journal of the American College of Cardiology 2014;64:2455-67.

111. Bachmann A, Tubaro A, Barber N, et al. 180-W XPS GreenLight laser vaporisation versus transurethral resection of the prostate for the treatment of benign prostatic obstruction: 6-month safety and efficacy results of a European Multicentre Randomised Trial--the GOLIATH study. European Urology 2014;65:931-42.

112. Bath-Hextall F, Ozolins M, Armstrong SJ, et al. Surgical excision versus imiquimod $5 \%$ cream for nodular and superficial basal-cell carcinoma (SINS): A multicentre, non-inferiority, randomised controlled trial. The Lancet Oncology 2014;15:96-105.

113. Bikhazi N, Light J, Truitt T, et al. Standalone balloon dilation versus sinus surgery for chronic rhinosinusitis: A prospective, multicenter, randomized, controlled trial with 1-year follow-up. American Journal of Rhinology and Allergy 2014;28:323-9.

114. Chen S, Zhu L, Cai J, et al. Plasmakinetic enucleation of the prostate compared with open prostatectomy for prostates larger than 100 grams: A randomized 
noninferiority controlled trial with long-term results at 6 years. European Urology 2014;66:284-91.

115.Djehdian LM, Araujo MP, Takano CC, et al.

Transobturator sling compared with single-incision minisling for the treatment of stress urinary incontinence: A randomized controlled trial. Obstetrics and Gynecology 2014;123:553-61.

116. Donker M, van Tienhoven G, Straver ME, et al. Radiotherapy or surgery of the axilla after a positive sentinel node in breast cancer (EORTC 10981-22023 AMAROS): A randomised, multicentre, open-label, phase 3 non-inferiority trial. The Lancet Oncology 2014;15:1303-10.

117. Han Y, Xu B, Jing Q, et al. A randomized comparison of novel biodegradable polymer-and durable polymercoated cobalt-chromium sirolimus-eluting stents. JACC: Cardiovascular Interventions 2014;7:1352-60.

118. Hisey MS, Bae HW, Davis R, et al. Multi-center, prospective, randomized, controlled investigational device exemption clinical trial comparing mobi-C cervical artificial disc to anterior discectomy and fusion in the treatment of symptomatic degenerative disc disease in the cervical spine. International Journal of Spine Surgery 2014;8 (no pagination).

119.Jeong SY, Park JW, Nam BH, et al. Open versus laparoscopic surgery for mid-rectal or low-rectal cancer after neoadjuvant chemoradiotherapy (COREAN trial): Survival outcomes of an open-label, non-inferiority, randomised controlled trial. The Lancet Oncology 2014;15:767-74.

120. Kim KB, Hwang HY, Hahn S, et al. A randomized comparison of the Saphenous Vein Versus Right Internal Thoracic Artery as a Y-Composite Graft (SAVE RITA) trial: One-year angiographic results and mid-term clinical outcomes. Journal of Thoracic \& Cardiovascular Surgery 2014;148:901-7; discussion 7-8.

121.Lee JY, Park DW, Kim YH, et al. Comparison of biolimus A9-eluting (Nobori) and everolimus-eluting (Promus Element) stents in patients with de novo native long coronary artery lesions: A randomized long drug-eluting stent $v$ trial. Circulation: Cardiovascular Interventions 2014;7:322-9.

122.McDougall CG, Johnston SC, Gholkar A, et al. Bioactive versus bare platinum coils in the treatment of intracranial aneurysms: The MAPS (matrix and platinum science) trial. American Journal of Neuroradiology 2014;35:935-42.

123. Minguez JRL, Asensio JMN, Vecino LJD, et al. A prospective randomised study of the paclitaxel-coated balloon catheter in bifurcated coronary lesions (babilon trial): 24-month clinical and angiographic results. EuroIntervention 2014;10:50-7.

124. Nelson PR, Kracjer Z, Kansal N, et al. A multicenter, randomized, controlled trial of totally percutaneous access versus open femoral exposure for endovascular aortic aneurysm repair (the PEVAR trial). Journal of Vascular Surgery 2014;59:1181-93.

125.Park KW, Kang SH, Kang HJ, et al. A randomized comparison of platinum chromium-based everolimuseluting stents versus cobalt chromium-based zotarolimuseluting stents in all-comers receiving percutaneous coronary intervention: HOST-ASSURE noninferiority trial. Journal of the American College of Cardiology 2014;A. 63:2805-16.

126.Pilgrim T, Heg D, Roffi M, et al. Ultrathin strut biodegradable polymer sirolimus-eluting stent versus durable polymer everolimus-eluting stent for percutaneous coronary revascularisation (BIOSCIENCE): A randomised, single-blind, non-inferiority trial. The Lancet 2014;384:2111-22.

127. Qian J, Zhang YJ, Xu B, et al. Optical coherence tomography assessment of a PLGA-polymer with electrografting base layer versus a PLA-polymer sirolimuseluting stent at three-month follow-up: the BuMA-OCT randomised trial. EuroIntervention 2014;10:806-14.

128. Saito S, Valdes-Chavarri M, Richardt G, et al. A randomized, prospective, intercontinental evaluation of a bioresorbable polymer sirolimus-eluting coronary stent system: The CENTURY II (Clinical Evaluation of New Terumo Drug-Eluting Coronary Stent System in the Treatment of Patients with Coronary Artery Disease) trial. European Heart Journal 2014;35:2021-31.

129. Schellart RP, Oude Rengerink K, Van Der Aa F, et al. A randomized comparison of a single-incision midurethral sling and a transobturator midurethral sling in women with stress urinary incontinence: Results of 12-mo followup. European Urology 2014;66:1179-85.

130. Tanaka A, Sadahiro S, Suzuki T, et al. Randomized controlled trial comparing subcuticular absorbable suture with conventional interrupted suture for wound closure at elective operation of colon cancer. Surgery (United States) 2014;155:486-92.

131.van den Bos RR, Malskat WS, De Maeseneer MG, et al. Randomized clinical trial of endovenous laser ablation versus steam ablation (LAST trial) for great saphenous varicose veins. British Journal of Surgery 2014;101:1077-83. 
132. Von Birgelen C, Sen H, Lam MK, et al. Third-generation zotarolimus-eluting and everolimus-eluting stents in all-comer patients requiring a percutaneous coronary intervention (DUTCH PEERS): A randomised, singleblind, multicentre, non-inferiority trial. The Lancet 2014;383:413-23.

133.Xu B, Gao R, Wang J, et al. A prospective, multicenter, randomized trial of paclitaxel-coated balloon versus paclitaxel-eluting stent for the treatment of drug-eluting stent in-stent restenosis: Results from the PEPCAD China ISR trial. JACC: Cardiovascular Interventions 2014;7:204-11.

134. Yuan F, Chen X, Song XT, et al. Novel completed biodegradable polymer sirolimus-eluting stent versus durable polymer sirolimus-eluting stent in de novo lesions: Nine-month angiographic and three-year clinical outcomes of hope trial. Chinese Medical Journal 2014;127:2561-6.

135.Zeller T, Baumgartner I, Scheinert D, et al. Drugeluting balloon versus standard balloon angioplasty for infrapopliteal arterial revascularization in critical limb ischemia: 12-Month results from the IN.PACT deep randomized trial. Journal of the American College of Cardiology 2014;64:1568-76.

136.Zhang Q, Qiu JP, Kirtane AJ, et al. Comparison of biodegradable polymer versus durable polymer sirolimuseluting stenting in patients with acute st-elevation myocardial infarction undergoing primary percutaneous coronary intervention: Results of the RESOLVE study. Journal of Interventional Cardiology 2014;27:131-41.

137. Abrishamkar S, Kouchakzadeh M, Mirhosseini A, et al. Comparison of open surgical discectomy versus plasmalaser nucleoplasty in patients with single lumbar disc herniation. Journal of Research in Medical Sciences 2015;20:1133-7.

138. Banhiran W, Assanasen P, Tantilipikorn P, et al. A randomized study of temperature-controlled versus bipolar radiofrequency for inferior turbinate reduction. European Archives of Oto-Rhino-Laryngology 2015;272:2877-84.

139. Baumhauer JF, Singh D, Glazebrook M, et al. Prospective, Randomized, Multi-centered Clinical Trial Assessing Safety and Efficacy of a Synthetic Cartilage Implant Versus First Metatarsophalangeal Arthrodesis in Advanced Hallux Rigidus. Foot and Ankle International 2015;37:457-69.

140. Bonjer HJ, Deijen CL, Abis GA, et al. A randomized trial of laparoscopic versus open surgery for rectal cancer. $\mathrm{N}$ Engl J Med 2015;372:1324-32.

141. Brouwer PA, Brand R, Van Den Akker-Van Marle ME, et al. Percutaneous laser disc decompression versus conventional microdiscectomy in sciatica: A randomized controlled trial. Spine Journal 2015;15:857-65.

142. Cooper NAM, Clark TJ, Middleton L, et al. Outpatient versus inpatient uterine polyp treatment for abnormal uterine bleeding: Randomised controlled non-inferiority study. BMJ (Online) 2015;350 (no pagination).

143. Detollenaere RJ, den Boon J, Stekelenburg J, et al. Sacrospinous hysteropexy versus vaginal hysterectomy with suspension of the uterosacral ligaments in women with uterine prolapse stage 2 or higher: multicentre randomised non-inferiority trial. BMJ 2015;351:h3717.

144.Di Costanzo GG, Tortora R, D'Adamo G, et al. Radiofrequency ablation versus laser ablation for the treatment of small hepatocellular carcinoma in cirrhosis: A randomized trial. Journal of Gastroenterology and Hepatology (Australia) 2015;30:559-65.

145. Dukkipati SR, Cuoco F, Kutinsky I, et al. Pulmonary Vein Isolation Using the Visually Guided Laser Balloon A Prospective, Multicenter, and Randomized Comparison to Standard Radiofrequency Ablation. Journal of the American College of Cardiology 2015;66:1350-60.

146. Ellis SG, Kereiakes DJ, Metzger DC, et al. Everolimuseluting bioresorbable scaffolds for coronary artery disease. New England Journal of Medicine 2015;373:1905-15.

147.Elshal AM, Elkoushy MA, El-Nahas AR, et al. GreenLight $^{\mathrm{TM}}$ laser (XPS) photoselective vapo-enucleation versus holmium laser enucleation of the prostate for the treatment of symptomatic benign prostatic hyperplasia: a randomized controlled study. Journal of urology 2015;193:927-34.

148. Fleshman J, Branda M, Sargent DJ, et al. Effect of laparoscopic-assisted resection vs open resection of stage II or III rectal cancer on pathologic outcomes the ACOSOG Z6051 randomized clinical trial. JAMA - Journal of the American Medical Association 2015;314:1346-55.

149. Gao R, Yang Y, Han Y, et al. Bioresorbable Vascular Scaffolds Versus Metallic Stents in Patients With Coronary Artery Disease: ABSORB China Trial. Journal of the American College of Cardiology 2015;66:2298-309.

150. Garcia R, Yue JJ, Blumenthal S, et al. Lumbar total disc replacement for discogenic low back pain: Two-year outcomes of the activL multicenter randomized controlled IDE clinical trial. Spine 2015;40:1873-81.

151. Genereux P, Kumsars I, Lesiak M, et al. A randomized trial of a dedicated bifurcation stent versus provisional stenting in the treatment of coronary bifurcation lesions. Journal of the American College of Cardiology 2015;65:533-43.

152. Gotohda N, Yamanaka T, Saiura A, et al. Impact of energy 
devices during liver parenchymal transection: a multicenter randomized controlled trial. World Journal of Surgery 2015;39:1543-9.

153. Hayashi T, Kawakami H, Osanai M, et al. No Benefit of Endoscopic Sphincterotomy Before Biliary Placement of Self-Expandable Metal Stents for Unresectable Pancreatic Cancer. Clinical Gastroenterology and Hepatology 2015;13:1151-8.e2.

154.Hirao M, Kurokawa Y, Fujita J, et al. Long-term outcomes after prophylactic bursectomy in patients with resectable gastric cancer: Final analysis of a multicenter randomized controlled trial. Surgery (United States) 2015;157:1099-105.

155.Kaiser C, Galatius S, Jeger R, et al. Long-term efficacy and safety of biodegradable-polymer biolimus-eluting stents : Main results of the basel stent kosten-effektivitats trial-prospective validation examination II (BASKETPROVE II), A randomized, controlled noninferiority 2-year outcome trial. Circulation 2015;131:74-81.

156. Kehoe S, Hook J, Nankivell M, et al. Primary chemotherapy versus primary surgery for newly diagnosed advanced ovarian cancer (CHORUS): An open-label, randomised, controlled, non-inferiority trial. The Lancet 2015;386:249-57.

157. Kereiakes DJ, Meredith IT, Windecker S, et al. Efficacy and safety of a novel bioabsorbable polymer-coated, everolimus-eluting coronary stent: the EVOLVE II Randomized Trial. Circulation: Cardiovascular Interventions 2015;8.

158. Kim JW, Jang JY, Lee CK, et al. Comparison of hemostatic forceps with soft coagulation versus argon plasma coagulation for bleeding peptic ulcer--a randomized trial. Endoscopy 2015;47:680-7.

159. Kimura T, Kozuma K, Tanabe K, et al. A randomized trial evaluating everolimus-eluting Absorb bioresorbable scaffolds vs. everolimus-eluting metallic stents in patients with coronary artery disease: ABSORB Japan. European Heart Journal 2015;36:3332-42.

160.Lemos PA, Abizaid AAC, Meireles GC, et al. Metallic Limus-Eluting Stents Abluminally Coated with Biodegradable Polymers: Angiographic and Clinical Comparison of a Novel Ultra-Thin Sirolimus Stent Versus Biolimus Stent in the DESTINY Randomized Trial. Cardiovascular Therapeutics 2015;33:367-71.

161.Luik A, Radzewitz A, Kieser M, et al. Cryoballoon Versus Open Irrigated Radiofrequency Ablation in Patients With Paroxysmal Atrial Fibrillation: The Prospective, Randomized, Controlled, Noninferiority FreezeAF Study.
Circulation 2015;132:1311-9.

162.Park SJ, Ahn JM, Kim YH, et al. Trial of everolimuseluting stents or bypass surgery for coronary disease. New England Journal of Medicine 2015;372:1204-12.

163. Patel VV, Whang PG, Haley TR, et al. Superion Interspinous Process Spacer for Intermittent Neurogenic Claudication Secondary to Moderate Lumbar Spinal Stenosis: Two-Year Results from a Randomized Controlled FDA-IDE Pivotal Trial. Spine 2015;40:275-82.

164. Raungaard B, Jensen LO, Tilsted HH, et al. Zotarolimuseluting durable-polymer-coated stent versus a biolimuseluting biodegradable-polymer-coated stent in unselected patients undergoing percutaneous coronary intervention (SORT OUT VI): A randomised non-inferiority trial. The Lancet 2015;385:1527-35.

165. Rosenfield K, Jaff MR, White CJ, et al. Trial of a paclitaxel-coated balloon for femoropopliteal artery disease. New England Journal of Medicine 2015;373:145-53.

166. Salminen P, Paajanen H, Rautio T, et al. Antibiotic therapy vs appendectomy for treatment of uncomplicated acute appendicitis: The APPAC randomized clinical trial. JAMA - Journal of the American Medical Association 2015;313:2340-8.

167. Sonksen J, Barber NJ, Speakman MJ, et al. Prospective, randomized, multinational study of prostatic urethral lift versus transurethral resection of the prostate: 12 -month results from the BPH6 study. European Urology 2015;68:643-52.

168. Stevenson ARL, Solomon MJ, Lumley JW, et al. Effect of laparoscopic-assisted resection vs open resection on pathological outcomes in rectal cancer: The ALaCaRT randomized clinical trial. JAMA - Journal of the American Medical Association 2015;314:1356-63.

169. Tutton SM, Pflugmacher R, Davidian M, et al. KAST Study: The kiva system as a vertebral augmentation treatment-A safety and effectiveness trial: A randomized, noninferiority trial comparing the kiva system with balloon kyphoplasty in treatment of osteoporotic vertebral compression fractures. Spine 2015;40:865-75.

170.Urban P, Meredith IT, Abizaid A, et al. Polymer-free drugcoated coronary stents in patients at high bleeding risk. New England Journal of Medicine 2015;373:2038-47.

171. Windecker S, Haude M, Neumann FJ, et al. Comparison of a novel biodegradable polymer sirolimus-eluting stent with a durable polymer everolimus-eluting stent: Results of the randomized BIOFLOW-II trial. Circulation: Cardiovascular Interventions 2015;8 (2) (no pagination). 
172.Zurakowski A, Buszman PP, Milewski KP, et al. Stenting and Adjunctive Delivery of Paclitaxel Via Balloon Coating Versus Durable Polymeric Matrix for de Novo Coronary Lesions: Clinical and Angiographic Results from the Prospective Randomized Trial. Journal of Interventional Cardiology 2015;28:348-57.

173. Arnold PM, Sasso RC, Janssen ME, et al. Efficacy of i-factor bone graft versus autograft in anterior cervical discectomy and fusion results of the prospective, randomized, single-blinded food and drug administration investigational device exemption study. Spine 2016;41:1075-83.

174. Bisdas T, Borowski M, Stavroulakis K, et al. Endovascular Therapy Versus Bypass Surgery as First-Line Treatment Strategies for Critical Limb Ischemia: Results of the Interim Analysis of the CRITISCH Registry. JACC: Cardiovascular Interventions 2016;9:2557-65.

175. Boersma LV, van der Voort $\mathrm{P}$, Debruyne $\mathrm{P}$, et al. Multielectrode Pulmonary Vein Isolation Versus Single Tip Wide Area Catheter Ablation for Paroxysmal Atrial Fibrillation: A Multinational Multicenter Randomized Clinical Trial. Circulation: Arrhythmia and Electrophysiology 2016;9:e003151.

176. Cote GA, Slivka A, Tarnasky P, et al. Effect of covered metallic stents compared with plastic stents on benign biliary stricture resolution: A randomized clinical trial. JAMA - Journal of the American Medical Association 2016;315:1250-7.

177. Delawi D, Jacobs W, Van Susante JLC, et al. OP-1 compared with iliac crest autograft in instrumented posterolateral fusion a randomized, multicenter noninferiority trial. Journal of Bone and Joint Surgery American Volume 2016;98:441-8.

178. Dreyer K, Lier MCI, Emanuel MH, et al. Hysteroscopic proximal tubal occlusion versus laparoscopic salpingectomy as a treatment for hydrosalpinges prior to IVF or ICSI: An RCT. Human Reproduction 2016;31:2005-16.

179. Ishiwatari H, Kawakami H, Hisai H, et al. Balloon catheter versus basket catheter for endoscopic bile duct stone extraction: A multicenter randomized trial. Endoscopy 2016;48:350-7.

180.Jensen LO, Thayssen P, Maeng M, et al. Randomized Comparison of a Biodegradable Polymer Ultrathin Strut Sirolimus-Eluting Stent With a Biodegradable Polymer Biolimus-Eluting Stent in Patients Treated With Percutaneous Coronary Intervention: The SORT OUT VII Trial. Circulation: Cardiovascular Interventions 2016;9:07.
181.Kuck KH, Brugada J, Furnkranz A, et al. Cryoballoon or radiofrequency ablation for paroxysmal atrial fibrillation. New England Journal of Medicine 2016;374:2235-45.

182.Lee TH, Choi JH, Park DH, et al. Similar Efficacies of Endoscopic Ultrasound-guided Transmural and Percutaneous Drainage for Malignant Distal Biliary Obstruction. Clinical Gastroenterology and Hepatology 2016;14:1011-9.

183.Lee JH, Kong CB, Yang JJ, et al. Comparison of fusion rate and clinical results between $\mathrm{CaO}-\mathrm{SiO}<$ sub $>2</$ sub $>-$ $\mathrm{P}<$ sub $>2</$ sub $>\mathrm{O}<$ sub $>5</$ sub $>-\mathrm{B}<$ sub $>2</$ sub $>\mathrm{O}<$ sub $>3<1$ sub $>$ bioactive glass ceramics spacer with titanium cages in posterior lumbar interbody fusion. Spine Journal: Official Journal of the North American Spine Society 2016;16:1367-76.

184.Leon MB, Smith CR, Mack MJ, et al. Transcatheter or surgical aortic-valve replacement in intermediaterisk patients. New England Journal of Medicine 2016;374:1609-20.

185. Makikallio T, Holm NR, Lindsay M, et al. Percutaneous coronary angioplasty versus coronary artery bypass grafting in treatment of unprotected left main stenosis (NOBLE): a prospective, randomised, open-label, non-inferiority trial. The Lancet 2016;388:2743-52.

186. Martinkevich P, Rahbek O, Stilling M, et al. Is structural hydroxyapatite tricalcium-phosphate graft or tricortical iliac crest autograft better for calcaneal lengthening osteotomy in childhood? interim results from a randomised, controlled non-inferiority study. Bone \& Joint Journal 2016;98-B:1554-62.

187. Mehanna H, Wong WL, McConkey CC, et al. PETCT surveillance versus neck dissection in advanced head and neck cancer. New England Journal of Medicine 2016;374:1444-54.

188. Midy D, Papon X, Patra P, et al. Randomized Study of Noninferiority Comparing Prosthetic and Autologous Vein Above-Knee Femoropopliteal Bypasses. Annals of Vascular Surgery 2016;31:99-104.

189. Park SK, Ko BM, Han JP, et al. A prospective randomized comparative study of cold forceps polypectomy by using narrow-band imaging endoscopy versus cold snare polypectomy in patients with diminutive colorectal polyps. Gastrointestinal Endoscopy 2016;83:527-32.e1.

190.Pleva L, Kukla P, Kusnierova P, et al. Comparison of the Efficacy of Paclitaxel-Eluting Balloon Catheters and Everolimus-Eluting Stents in the Treatment of Coronary In-Stent Restenosis: The Treatment of In-Stent Restenosis Study. Circulation: Cardiovascular Interventions 
2016;9:e003316.

191. Rosenfield K, Matsumura JS, Chaturvedi S, et al.

Randomized trial of stent versus surgery for asymptomatic carotid stenosis. New England Journal of Medicine 2016;374:1011-20.

192. Sabate M, Windecker S, Iniguez A, et al. Everolimuseluting bioresorbable stent vs. durable polymer everolimuseluting metallic stent in patients with ST-segment elevation myocardial infarction: Results of the randomized ABSORB ST-segment elevation myocardial infarctionTROFI II trial. European Heart Journal 2016;37:229-40.

193. Sakamoto Y, Hori S, Oguro S, et al. Delayed Gastric Emptying After Stapled Versus Hand-Sewn Anastomosis of Duodenojejunostomy in Pylorus-Preserving Pancreaticoduodenectomy: a Randomized Controlled trial. Journal of Gastrointestinal Surgery 2016;20:595-603.

194. Serruys PW, Chevalier B, Sotomi Y, et al. Comparison of an everolimus-eluting bioresorbable scaffold with an everolimus-eluting metallic stent for the treatment of coronary artery stenosis (ABSORB II): a 3 year, randomised, controlled, single-blind, multicentre clinical trial. The Lancet 2016;388:2479-91.

195.Stefan V, Ahmed AK, Didier C, et al. Direct implantation of rapamycin-eluting stents with bioresorbable drug carrier technology utilising the svelte coronary stent-on-a-wire: The direct II study. EuroIntervention 2016;12:e615-e22.

196. Stone GW, Sabik JF, Serruys PW, et al. Everolimus-eluting Stents or bypass surgery for left main coronary artery disease. New England Journal of Medicine 2016;375:2223-35.

197.von Birgelen C, Kok MM, van der Heijden LC, et al. Very thin strut biodegradable polymer everolimus-eluting and sirolimus-eluting stents versus durable polymer zotarolimus-eluting stents in allcomers with coronary artery disease (BIO-RESORT): a three-arm, randomised, non-inferiority trial. The Lancet 2016;388:2607-17.

198. Witzigmann H, Diener MK, Kissenkotter S, et al. No need for routine drainage after pancreatic head resection: The dual-center, randomized, controlled PANDRA trial (ISRCTN04937707). Annals of Surgery 2016;264:528-35.

199.Xu B, Gao R, Yang Y, et al. Biodegradable Polymer-Based Sirolimus-Eluting Stents With Differing Elution and Absorption Kinetics: The PANDA III Trial. Journal of the American College of Cardiology 2016;67:2249-58.

200.Zhang H, Wang X, Deng W, et al. Randomized clinical trial comparing abluminal biodegradable polymer sirolimus-eluting stents with durable polymer sirolimuseluting stents Nine months angiographic and 5-year clinical outcomes. Medicine (United States) 2016;95 (38) (no pagination).

201. Ando K, Ishii K, Tada E, et al. Prospective multi-center registry to evaluate efficacy and safety of the newly developed diamond-like carbon-coated cobalt-chromium coronary stent system. Cardiovascular Intervention and Therapeutics 2017;32:225-32.

202.Arezzo A, Passera R, Bullano A, et al. Multi-port versus single-port cholecystectomy: results of a multi-centre, randomised controlled trial (MUSIC trial). Surgical Endoscopy 2017;31:2872-80.

203. Bondi J, Avdagic J, Karlbom U, et al. Randomized clinical trial comparing collagen plug and advancement flap for trans-sphincteric anal fistula. British Journal of Surgery 2017;104:1160-6.

204. Borgstrom A, Nerfeldt P, Friberg D. Adenotonsillotomy versus adenotonsillectomy in pediatric obstructive sleep apnea: An RCT. Pediatrics 2017;139 (4) (no pagination).

205. Chae IH, Yoon CH, Park JJ, et al. Comparison of DrugEluting Balloon Followed by Bare Metal Stent with Drug-Eluting Stent for Treatment of de Novo Lesions: Randomized, Controlled, Single-Center Clinical Trial. Journal of Korean Medical Science 2017;32:933-41.

206. Cho JH, Lee JH, Yeom JS, et al. Efficacy of Escherichia coli-derived recombinant human bone morphogenetic protein-2 in posterolateral lumbar fusion: an open, activecontrolled, randomized, multicenter trial. Spine Journal 2017;17:1866-74.

207. Deimling TA, Eldridge JL, Riley KA, et al. Randomized controlled trial comparing operative times between standard and robot-assisted laparoscopic hysterectomy. International Journal of Gynecology and Obstetrics 2017;136:64-9.

208. Erlandsson J, Holm T, Pettersson D, et al. Optimal fractionation of preoperative radiotherapy and timing to surgery for rectal cancer (Stockholm III): a multicentre, randomised, non-blinded, phase 3, non-inferiority trial. The Lancet Oncology 2017;18:336-46.

209. Fajadet J, Neumann FJ, Hildick-Smith D, et al. Twelvemonth results of a prospective, multicentre trial to assess the everolimus-eluting coronary stent system (PROMUS Element): The PLATINUM PLUS all-comers randomised trial. EuroIntervention 2017;12:1595-604.

210.Fernandez-Gonzalez S, Martinez Franco E, Lin Miao X, et al. Contasure-needleless ${ }^{\circledR}$ compared with Monarc ${ }^{\circledR}$ for the treatment of stress urinary incontinence. International urogynecology journal 2017;28:1077 84.

211.Ferrero-De-Loma-Osorio A, Garcia-Fernandez A, Castillo-Castillo J, et al. Time-to-Effect-Based Dosing 
Strategy for Cryoballoon Ablation in Patients with Paroxysmal Atrial Fibrillation: Results of the plusONE Multicenter Randomized Controlled Noninferiority Trial. Circulation: Arrhythmia and Electrophysiology 2017;10

(12) (no pagination).

212. Franzone A, Zaugg S, Piccolo R, et al. A randomized multicenter trial comparing the XIENCE everolimus eluting stent with the CYPHER sirolimus eluting stent in the treatment of female patients with de novo coronary artery lesions: The SPIRIT WOMEN study. PLoS ONE 2017;12 (8) (no pagination).

213. Fujita S, Mizusawa J, Kanemitsu Y, et al. Mesorectal Excision With or Without Lateral Lymph Node Dissection for Clinical Stage II/III Lower Rectal Cancer (JCOG0212): A Multicenter, Randomized Controlled, Noninferiority Trial. Annals of Surgery 2017;266:201-7.

214. Gornet MF, Lanman TH, Burkus JK, et al. Cervical disc arthroplasty with the Prestige LP disc versus anterior cervical discectomy and fusion, at 2 levels: Results of a prospective, multicenter randomized controlled clinical trial at 24 months. Journal of Neurosurgery: Spine 2017;26:653-67.

215. Hahn JY, Choi SH, Jeong JO, et al. Conservative versus aggressive treatment strategy with angiographic guidance alone in patients with intermediate coronary lesions: The SMART-CASE randomized, non-inferiority trial. International Journal of Cardiology 2017;240:114-9.

216. Huddart RA, Birtle A, Maynard L, et al. Clinical and patient-reported outcomes of SPARE - a randomised feasibility study of selective bladder preservation versus radical cystectomy. BJU International 2017;120:639-50.

217. Kandzari DE, Smits PC, Love MP, et al. Randomized Comparison of Ridaforolimus- and Zotarolimus-Eluting Coronary Stents in Patients With Coronary Artery Disease: Primary Results From the BIONICS Trial (BioNIR Ridaforolimus-Eluting Coronary Stent System in Coronary Stenosis). Circulation 2017;136:1304-14.

218. Kandzari DE, Mauri L, Koolen JJ, et al. Ultrathin, bioresorbable polymer sirolimus-eluting stents versus thin, durable polymer everolimus-eluting stents in patients undergoing coronary revascularisation (BIOFLOW V): a randomised trial. The Lancet 2017;390:1843-52.

219. Kang SH, Chung WY, Lee JM, et al. Angiographic outcomes of Orsiro biodegradable polymer sirolimuseluting stents and Resolute Integrity durable polymer zotarolimus-eluting stents: Results of the ORIENT trial. EuroIntervention 2017;12:1623-31.

220. Kitano S, Inomata M, Mizusawa J, et al. Survival outcomes following laparoscopic versus open D3 dissection for stage II or III colon cancer (JCOG0404): a phase 3, randomised controlled trial. The Lancet Gastroenterology and Hepatology 2017;2:261-8.

221.Lee HJ, Chung MJ, Park JY, et al. A prospective randomized study for efficacy of an uncovered double bare metal stent compared to a single bare metal stent in malignant biliary obstruction. Surgical Endoscopy 2017;31:3159-67.

222. Reardon MJ, Van Mieghem NM, Popma JJ, et al. Surgical or transcatheter aortic-valve replacement in intermediaterisk patients. New England Journal of Medicine 2017;376:1321-31.

223. Rillig A, Schmidt B, Di Biase L, et al. Manual Versus Robotic Catheter Ablation for the Treatment of Atrial Fibrillation: The Man and Machine Trial. JACC: Clinical Electrophysiology 2017;3:875-83.

224. Rogers JG, Pagani FD, Tatooles AJ, et al. Intrapericardial left ventricular assist device for advanced heart failure. New England Journal of Medicine 2017;376:451-60.

225. Sabadell J, Palau-Gené M, Huguet E, et al. Multicentre randomized trial of the Ajust ${ }^{\mathrm{TM}}$ single-incision sling compared to the Align ${ }^{\mathrm{TM}}$ transobturator tape sling. International urogynecology journal 2017;28:1041 7.

226. Salehi S, Avall-Lundqvist E, Legerstam B, et al. Robotassisted laparoscopy versus laparotomy for infrarenal paraaortic lymphadenectomy in women with highrisk endometrial cancer: A randomised controlled trial. European Journal of Cancer 2017;79:81-9.

227. Sano T, Sasako M, Mizusawa J, et al. Randomized Controlled Trial to Evaluate Splenectomy in Total Gastrectomy for Proximal Gastric Carcinoma. Annals of Surgery 2017;265:277-83.

228. Savolt A, Peley G, Polgar C, et al. Eight-year follow up result of the OTOASOR trial: The Optimal Treatment Of the Axilla - Surgery Or Radiotherapy after positive sentinel lymph node biopsy in early-stage breast cancer: A randomized, single centre, phase III, non-inferiority trial. European Journal of Surgical Oncology 2017;43:672-9.

229. Shera TA, Choh NA, Gojwari TA, et al. A comparison of imaging guided double percutaneous aspiration injection and surgery in the treatment of cystic echinococcosis of liver. British Journal of Radiology 2017;90 (1072) (no pagination).

230. Suh BG, Ahn MW, Kim HJ, et al. Wedge-shaped resection of the posterior bony arch during open door laminoplasty to prevent postoperative motion limitation. Spine 2017;42:143-50. 
231. Teeuwen K, van der Schaaf RJ, Adriaenssens T, et al. Randomized Multicenter Trial Investigating Angiographic Outcomes of Hybrid Sirolimus-Eluting Stents With Biodegradable Polymer Compared With EverolimusEluting Stents With Durable Polymer in Chronic Total Occlusions: The PRISON IV Trial. JACC: Cardiovascular Interventions 2017;10:133-43.

232. Tew JM, Strong MJ, Alexanderwest G, et al. A pivotal randomized clinical trial evaluating the safety and effectiveness of a novel hydrogel dural sealant as an adjunct to dural repair. Operative Neurosurgery 2017;13:204-12.

233. Worthley SG, Kirtane AJ, Simon DI, et al. First-inHuman Evaluation of a Novel Polymer-Free Drug-Filled Stent: Angiographic, IVUS, OCT, and Clinical Outcomes From the RevElution Study. JACC: Cardiovascular Interventions 2017;10:147-56.

234.Abdel-Wahab M, Toelg R, Byrne RA, et al. High-Speed Rotational Atherectomy Versus Modified Balloons Prior to Drug-Eluting Stent Implantation in Severely Calcified Coronary Lesions. Circulation: Cardiovascular Interventions 2018;11:e007415.

235.Abizaid A, Kedev S, Kedhi E, et al. Randomised comparison of a biodegradable polymer ultra-thin sirolimus-eluting stent versus a durable polymer everolimus-eluting stent in patients with de novo native coronary artery lesions: the meriT-V trial. Eurointervention 2018;14:e1207-e14.

236. Abt D, Hechelhammer L, Mullhaupt G, et al. Comparison of prostatic artery embolisation (PAE) versus transurethral resection of the prostate (TURP) for benign prostatic hyperplasia: Randomised, open label, non-inferiority trial. BMJ (Online) 2018;361 (no pagination).

237.Baan J, Claessen BE, Dijk KBV, et al. A Randomized Comparison of Paclitaxel-Eluting Balloon Versus Everolimus-Eluting Stent for the Treatment of Any InStent Restenosis: The DARE Trial. JACC: Cardiovascular Interventions 2018;11:275-83.

238. Barbaro NM, Quigg M, Ward MM, et al. Radiosurgery versus open surgery for mesial temporal lobe epilepsy: The randomized, controlled ROSE trial. Epilepsia 2018;59:1198-207.

239. Barendse RM, Musters GD, De Graaf EJR, et al. Randomised controlled trial of transanal endoscopic microsurgery versus endoscopic mucosal resection for large rectal adenomas (TREND Study). Gut 2018;67:837-46.

240. Chen YD, Li W, Guan C, et al. Comparison of 2 Different Drug-Coated Balloons in In-Stent Restenosis: The RESTORE ISR China Randomized Trial. JACC:
Cardiovascular Interventions 2018;11:2368-77.

241. de Goede B, Wijsmuller AR, van Ramshorst GH, et al. Watchful Waiting Versus Surgery of Mildly Symptomatic or Asymptomatic Inguinal Hernia in Men Aged 50 Years and Older: A Randomized Controlled Trial. Annals of Surgery 2018;267:42-9.

242.de Winter RJ, Katagiri Y, Asano T, et al. A sirolimus-eluting bioabsorbable polymer-coated stent (MiStent) versus an everolimus-eluting durable polymer stent (Xience) after percutaneous coronary intervention (DESSOLVE III): a randomised, single-blind, multicentre, non-inferiority, phase 3 trial. The Lancet 2018;391:431-40.

243.Elshal AM, El-Nahas AR, Ghazy M, et al. Low-Power Vs High-Power Holmium Laser Enucleation of the Prostate: Critical Assessment through Randomized Trial. Urology 2018;121:58-65.

244. Feldman TE, Reardon MJ, Rajagopal V, et al. Effect of mechanically expanded vs self-expanding transcatheter aortic valve replacement on mortality and major adverse clinical events in high-risk patients with aortic stenosis the REPRISE III randomized clinical trial. JAMA - Journal of the American Medical Association 2018;319:27-37.

245. Franzini T, Moura RN, Bonifacio P, et al. Complex biliary stones management: Cholangioscopy versus papillary large balloon dilation - A randomized controlled trial. Endoscopy International Open 2018;6:E131-E8.

246. Gilling P, Barber N, Bidair M, et al. WATER: A Double-Blind, Randomized, Controlled Trial of Aquablation $<$ sup $><$ /sup $>$ vs Transurethral Resection of the Prostate in Benign Prostatic Hyperplasia. Journal of Urology 2018;199:1252-61.

247. Gray WA, Soga Y, Prem JT, et al. A polymer-coated, paclitaxel-eluting stent (Eluvia) versus a polymer-free, paclitaxel-coated stent (Zilver PTX) for endovascular femoropopliteal intervention (IMPERIAL): a randomised, non-inferiority trial. The Lancet 2018;392:1541-51.

248. Guagliumi G, Shimamura K, Sirbu V, et al. Temporal course of vascular healing and neoatherosclerosis after implantation of durable- or biodegradable-polymer drugeluting stents. European Heart Journal 2018;39:2448-56.

249.Han Y, Xu B, Fu G, et al. A Randomized Trial Comparing the NeoVas Sirolimus-Eluting Bioresorbable Scaffold and Metallic Everolimus-Eluting Stents. JACC: Cardiovascular Interventions 2018;11:260-72.

250. Hasanov M, Denschlag D, Seemann E, et al. Bipolar vessel-sealing devices in laparoscopic hysterectomies: a multicenter randomized controlled clinical trial. Archives of Gynecology and Obstetrics 2018;297:409-14. 
251.Jeger RV, Farah A, Ohlow MA, et al. Drug-coated balloons for small coronary artery disease (BASKET-SMALL 2): an open-label randomised non-inferiority trial. The Lancet 2018;392:849-56.

252.Jensen CJ, Richardt G, Tolg R, et al. Angiographic and clinical performance of a paclitaxel-coated balloon compared to a second-generation sirolimuseluting stent in patients with in-stent restenosis: The BIOLUX randomised controlled trial. EuroIntervention 2018;14:1096-103.

253. Kawamura T, Takeuchi Y, Asai S, et al. A comparison of the resection rate for cold and hot snare polypectomy for 4-9 mm colorectal polyps: a multicentre randomised controlled trial (CRESCENT study). Gut 2018;67:1950-7.

254. Kayama T, Sato S, Sakurada K, et al. Effects of surgery with salvage stereotactic radiosurgery versus surgery with whole-brain radiation therapy in patients with one to four brain metastases (JCOG0504): A Phase III, noninferiority, randomized controlled trial. Journal of Clinical Oncology 2018;36:3282-9.

255.Lansky A, Wijns W, Xu B, et al. Targeted therapy with a localised abluminal groove, low-dose sirolimus-eluting, biodegradable polymer coronary stent (TARGET All Comers): a multicentre, open-label, randomised noninferiority trial. The Lancet 2018;392:1117-26.

256. Lee TH, Park SH, Yang JK, et al. Is the isolated-tip needle-knife precut as effective as conventional precut fistulotomy in difficult biliary cannulation? Gut and Liver 2018;12:597-605.

257. Meyer B, Baranto A, Schils F, et al. Percutaneous interspinous spacer vs decompression in patients with neurogenic claudication: An alternative in selected patients? Neurosurgery 2018;82:621-9.

258. Mitchem JB, Stafford C, Francone TD, et al. What is the optimal management of an intra-operative air leak in a colorectal anastomosis? Colorectal Disease 2018;20:O39-O45.

259. Mordasini L, Di Bona C, Klein J, et al. 80-W GreenLight Laser Vaporization Versus Transurethral Resection of the Prostate for Treatment of Benign Prostatic Obstruction: 5-Year Outcomes of a Single-center Prospective Randomized Trial. Urology 2018;116:144-9.

260. Nakamura M, Otsuji S, Nakagawa Y, et al. Noninferiority of resolute integrity drug-eluting stent to benchmark Xience drug-eluting stent. Circulation Journal 2018;82:2284-91.

261. Nogueira RG, Frei D, Kirmani JF, et al. Safety and efficacy of a 3-dimensional stent retriever with aspiration-based thrombectomy vs aspiration-based thrombectomy alone in acute ischemic stroke intervention a randomized clinical trial. JAMA Neurology 2018;75:304-11.

262. Paik WH, Lee TH, Park DH, et al. EUS-Guided Biliary Drainage Versus ERCP for the Primary Palliation of Malignant Biliary Obstruction: A Multicenter Randomized Clinical Trial. American Journal of Gastroenterology 2018;113:987-97.

263.Palos CC, Maturana AP, Ghersel FR, et al. Prospective and randomized clinical trial comparing transobturator versus retropubic sling in terms of efficacy and safety. International Urogynecology Journal 2018;29:29-35.

264.Panchal R, Denhaese R, Hill C, et al. Anterior and lateral lumbar interbody fusion with supplemental interspinous process fixation: Outcomes from a multicenter, prospective, randomized, controlled study. International Journal of Spine Surgery 2018;12:172-84.

265.Papastergiou V, Paraskeva KD, Fragaki M, et al. Cold versus hot endoscopic mucosal resection for nonpedunculated colorectal polyps sized 6-10 mm: A randomized trial. Endoscopy 2018;50:403-11.

266. Paradies V, Ben-Yehuda O, Jonas M, et al. A prospective randomised trial comparing the novel ridaforolimuseluting BioNIR stent to the zotarolimus-eluting Resolute stent: Six-month angiographic and one-year clinical results of the NIREUS trial. EuroIntervention 2018;14:86-93.

267.Parekh DJ, Reis IM, Castle EP, et al. Robot-assisted radical cystectomy versus open radical cystectomy in patients with bladder cancer (RAZOR): an open-label, randomised, phase 3 , non-inferiority trial. The Lancet 2018;391:2525-36.

268. Pouw RE, Kunzli HT, Bisschops R, et al. Simplified versus standard regimen for focal radiofrequency ablation of dysplastic Barrett's oesophagus: a multicentre randomised controlled trial. The Lancet Gastroenterology and Hepatology 2018;3:566-74.

269. Price MJ, Shlofmitz RA, Spriggs DJ, et al. Safety and efficacy of the next generation Resolute Onyx zotarolimuseluting stent: Primary outcome of the RESOLUTE ONYX core trial. Catheterization and Cardiovascular Interventions 2018;92:253-9.

270. Ramirez PT, Frumovitz M, Pareja R, et al. Minimally Invasive versus Abdominal Radical Hysterectomy for Cervical Cancer. New England Journal of Medicine 2018;379:1895-904.

271. Ray AF, Powell J, Speakman MJ, et al. Efficacy and safety of prostate artery embolization for benign prostatic hyperplasia: an observational study and propensity- 
matched comparison with transurethral resection of the prostate (the UK-ROPE study). BJU International 2018;122:270-82.

272. Saito S, Krucoff MW, Nakamura S, et al. Japan-United States of America Harmonized Assessment by Randomized Multicentre Study of OrbusNEich's Combo StEnt (JapanUSA HARMONEE) study: Primary results of the pivotal registration study of combined endothelial progenitor cell capture and drug-eluting stent in patients with ischaemic coronary disease and non-ST-elevation acute coronary syndrome. European Heart Journal 2018;39:2460-8.

273. Schwaitzberg SD, Roberts K, Romanelli JR, et al. The NOVEL trial: natural orifice versus laparoscopic cholecystectomy-a prospective, randomized evaluation. Surgical Endoscopy 2018;32:2505-16.

274. Schwandner T, Thieme A, Scherer R, et al. Randomized clinical trial comparing a small intestinal submucosa anal fistula plug to advancement flap for the repair of complex anal fistulas. International Journal of Surgery Open 2018;15:25-31.

275. Stone GW, Ellis SG, Gori T, et al. Blinded outcomes and angina assessment of coronary bioresorbable scaffolds: 30day and 1-year results from the ABSORB IV randomised trial. The Lancet 2018;392:1530-40.

276. Tang Y, Qiao S, Su X, et al. Drug-Coated Balloon Versus Drug-Eluting Stent for Small-Vessel Disease: The RESTORE SVD China Randomized Trial. Jacc: Cardiovascular Interventions 2018;11:2381-92.

277. Tijssen RYG, Kraak RP, Hofma SH, et al. Complete two-year follow-up with formal non-inferiority testing on primary outcomes of the AIDA trial comparing the Absorb bioresorbable scaffold with the XIENCE drugeluting metallic stent in routine PCI. EuroIntervention 2018;14:e426-e33.

278. Van De Graaf VA, Noorduyn JCA, Willigenburg NW, et al. Effect of Early Surgery vs Physical Therapy on Knee Function among Patients with Nonobstructive Meniscal Tears: The ESCAPE Randomized Clinical Trial. JAMA - Journal of the American Medical Association 2018;320:1328-37.

279.von Birgelen C, Zocca P, Buiten RA, et al. Thin composite wire strut, durable polymer-coated (Resolute Onyx) versus ultrathin cobalt-chromium strut, bioresorbable polymercoated (Orsiro) drug-eluting stents in allcomers with coronary artery disease (BIONYX): an international, single-blind, randomised non-inferiority trial. The Lancet 2018;392:1235-45.

280.von Birgelen C, Asano T, Amoroso G, et al. First-in- man randomised comparison of the BuMA Supreme biodegradable polymer sirolimus-eluting stent versus a durable polymer zotarolimus-eluting coronary stent: the PIONEER trial. Eurointervention 2018;13:2026-35.

281. Walsh SJ, Hanratty CG, Watkins S, et al. Culotte stenting for coronary bifurcation lesions with $2 \mathrm{nd}$ and 3rd generation everolimus-eluting stents: The CELTIC bifurcation study. EuroIntervention 2018;14:e318-e24.

282.Xu K, Han Y, Xu B, et al. Efficacy and safety of a second generation biodegradable polymer sirolimus eluting stent: One year results of the CREDIT 2 trial. Cardiovascular Therapeutics 2018;36 (3) (no pagination).

283. Yamaji K, Zanchin T, Zanchin C, et al. Unselected use of ultrathin strut biodegradable polymer sirolimus-eluting stent versus durable polymer everolimus-eluting stent for coronary revascularization. Circulation: Cardiovascular Interventions 2018;11 (9) (no pagination).

284.Zou Z, Xu A, Zheng S, et al. Dual-centre randomizedcontrolled trial comparing transurethral endoscopic enucleation of the prostate using diode laser vs. bipolar plasmakinetic for the treatment of LUTS secondary of benign prostate obstruction: 1-year follow-up results. World Journal of Urology 2018;36:1117-26.

285. Balling H. Additional Sacroplasty Does Not Improve Clinical Outcome in Minimally Invasive NavigationAssisted Screw Fixation Procedures for Nondisplaced Insufficiency Fractures of the Sacrum. Spine 2019;44:534-42.

286. Belghazi K, Pouw RE, Koch AD, et al. Self-sizing radiofrequency ablation balloon for eradication of Barrett's esophagus: results of an international multicenter randomized trial comparing 3 different treatment regimens. Gastrointestinal Endoscopy 2019;90:415-23.

287. Belghazi K, Scholvinck DW, van Berge Henegouwen MI, et al. Results of a two-phased clinical study evaluating a new multiband mucosectomy device for early Barrett's neoplasia: a randomized pre-esophagectomy trial and a pilot therapeutic pilot study. Surgical Endoscopy 2019;33:2864-72.

288. Cremer M, Alfaro K, Garai J, et al. Evaluation of two alternative ablation treatments for cervical pre-cancer against standard gas-based cryotherapy: A randomized non-inferiority study. International Journal of Gynecological Cancer 2019;29:851-6.

289. Dua KS, DeWitt JM, Kessler WR, et al. A phase III, multicenter, prospective, single-blinded, noninferiority, randomized controlled trial on the performance of a novel esophageal stent with an antireflux valve (with video). 
Gastrointestinal Endoscopy 2019;90:64-74.e3.

290. Eisenschenk A, Spitzmuller R, Guthoff C, et al. Single versus dual Kirschner wires for closed reduction and intramedullary nailing of displaced fractures of the fifth metacarpal neck (1-2 KiWi): A randomized controlled trial. Bone and Joint Journal 2019;101-B:1263-71.

291. Ghobrial FK, Shoma A, Elshal AM, et al. Randomized Trial Comparing Bipolar Transurethral Vaporization of the Prostate versus GreenLight Laser (XPS-180Watt) Photoselective Vaporization of the Prostate for Treatment of small to moderate Benign Prostatic Obstruction: twoyears Outcome. BJU international 2019.

292.Hofmann A, Gorbulev S, Guehring T, et al. Autologous Iliac Bone Graft Compared with Biphasic Hydroxyapatite and Calcium Sulfate Cement for the Treatment of Bone Defects in Tibial Plateau Fractures: a Prospective, Randomized, Open-Label, Multicenter Study. Journal of bone and joint surgery American volume 2019.

293. Hoogeslag RAG, Brouwer RW, Boer BC, et al. Acute Anterior Cruciate Ligament Rupture: Repair or Reconstruction? Two-Year Results of a Randomized Controlled Clinical Trial. American Journal of Sports Medicine 2019;47:567-77.

294.Jansen MP, Besselink NJ, van Heerwaarden RJ, et al. Knee Joint Distraction Compared with High Tibial Osteotomy and Total Knee Arthroplasty: Two-Year Clinical, Radiographic, and Biochemical Marker Outcomes of Two Randomized Controlled Trials. Cartilage 2019.

295. Kawashima H, Hashimoto S, Ohno E, et al. Comparison of 8- and 10-mm diameter fully covered self-expandable metal stents: A multicenter prospective study in patients with distal malignant biliary obstruction. Digestive Endoscopy 2019;31:439-47.

296. Kenny D, Eicken A, Dahnert I, et al. A randomized, controlled, multi-center trial of the efficacy and safety of the Occlutech Figulla Flex-II Occluder compared to the Amplatzer Septal Occluder for transcatheter closure of secundum atrial septal defects. Catheterization \& Cardiovascular Interventions 2019;93:316-21.

297. Kim HH, Han SU, Kim MC, et al. Effect of Laparoscopic Distal Gastrectomy vs Open Distal Gastrectomy on Long-term Survival Among Patients With Stage I Gastric Cancer: The KLASS-01 Randomized Clinical Trial. JAMA Oncology 2019;5:506-13.

298. Kinoshita T, Uyama I, Terashima M, et al. Long-term Outcomes of Laparoscopic Versus Open Surgery for Clinical Stage II/III Gastric Cancer: a Multicenter Cohort Study in Japan (LOC-A Study). Annals of surgery
2019;269:887 94.

299.Lanz J, Kim WK, Walther T, et al. Safety and efficacy of a self-expanding versus a balloon-expandable bioprosthesis for transcatheter aortic valve replacement in patients with symptomatic severe aortic stenosis: a randomised noninferiority trial. The Lancet 2019;394:1619-28.

300.Li S, Xiao H, Yang L, et al. Electrospun P(LLA-CL) Nanoscale Fibrinogen Patch vs Porcine Small Intestine Submucosa Graft Repair of Inguinal Hernia in Adults: a Randomized, Single-Blind, Controlled, Multicenter, Non-Inferiority Trial. Journal of the American College of Surgeons 2019.

301.Lin HC, He QL, Shao WJ, et al. Partial stapled hemorrhoidopexy versus circumferential stapled hemorrhoidopexy for grade III to IV prolapsing hemorrhoids: A randomized, noninferiority trial. Diseases of the Colon and Rectum 2019;62:223-33.

302. Mack MJ, Leon MB, Thourani VH, et al. Transcatheter aortic-valve replacement with a balloon-expandable valve in low-risk patients. New England Journal of Medicine 2019;380:1695-705.

303. Maeng M, Christiansen EH, Raungaard B, et al. Everolimus-Eluting Versus Biolimus-Eluting Stents With Biodegradable Polymers in Unselected Patients Undergoing Percutaneous Coronary Intervention: A Randomized Noninferiority Trial With 1-Year FollowUp (SORT OUT VIII Trial). JACC: Cardiovascular Interventions 2019;12:624-33.

304. Maturana AP, Palos CC, Ghersel FR, et al. Randomized controlled trial comparing mini-sling with transobturator sling for the treatment of stress urinary incontinence. International Urogynecology Journal 2019.

305.Minaga K, Ogura T, Shiomi H, et al. Comparison of the efficacy and safety of endoscopic ultrasound-guided choledochoduodenostomy and hepaticogastrostomy for malignant distal biliary obstruction: Multicenter, randomized, clinical trial. Digestive Endoscopy 2019;31:575-82.

306. Moreu J, Moreno-Gómez R, Pérez de Prado A, et al. Firstin-man randomised comparison of the Angiolite durable fluoroacrylate polymer-based sirolimus-eluting stent versus a durable fluoropolymer-based everolimus-eluting stent in patients with coronary artery disease: the ANGIOLITE trial. EuroIntervention 2019;15:e1081 e9.

307. Mustapha JA, Brodmann M, Geraghty PJ, et al. Drugcoated vs uncoated percutaneous transluminal angioplasty in infrapopliteal arteries: Six-month results of the lutonix BTK trial. Journal of Invasive Cardiology 2019;31:205-11. 
308. Niemeyer P, Laute V, Zinser W, et al. A Prospective, Randomized, Open-Label, Multicenter, Phase III Noninferiority Trial to Compare the Clinical Efficacy of Matrix-Associated Autologous Chondrocyte Implantation With Spheroid Technology Versus Arthroscopic Microfracture for Cartilage Defects of the Knee. Orthopaedic Journal of Sports Medicine 2019;7.

309. Noriega D, Marcia S, Theumann N, et al. A prospective, international, randomized, noninferiority study comparing an implantable titanium vertebral augmentation device versus balloon kyphoplasty in the reduction of vertebral compression fractures (SAKOS study). Spine Journal 2019;19:1782-95.

310.Popma JJ, Michael Deeb G, Yakubov SJ, et al. Transcatheter aortic-valve replacement with a selfexpanding valve in low-risk patients. New England Journal of Medicine 2019;380:1706-15.

311. Rissanen TT, Uskela S, Eranen J, et al. Drug-coated balloon for treatment of de-novo coronary artery lesions in patients with high bleeding risk (DEBUT): a singleblind, randomised, non-inferiority trial. The Lancet 2019;394:230-9.

312. Robert M, Espalieu P, Pelascini E, et al. Efficacy and safety of one anastomosis gastric bypass versus Roux-en-Y gastric bypass for obesity (YOMEGA): a multicentre, randomised, open-label, non-inferiority trial. The Lancet 2019;393:1299-309.

313. Rozemeijer R, Stein M, Voskuil M, et al. Randomized AllComers Evaluation of a Permanent Polymer ZotarolimusEluting Stent Versus a Polymer-Free Amphilimus-Eluting Stent. Circulation 2019;139:67-77.

314. Saito S, Toelg R, Witzenbichler B, et al. BIOFLOW-IV, a randomised, intercontinental, multicentre study to assess the safety and effectiveness of the Orsiro sirolimus-eluting stent in the treatment of subjects with de novo coronary artery lesions: primary outcome target vessel failure at 12 months. Eurointervention 2019;15:e1006-e13.

315.Seo DW, Sherman S, Dua KS, et al. Covered and uncovered biliary metal stents provide similar relief of biliary obstruction during neoadjuvant therapy in pancreatic cancer: a randomized trial. Gastrointestinal Endoscopy 2019;90:602-12.e4.

316. Skoldenberg OG, Rysinska AD, Chammout G, et al. A randomized double-blind noninferiority trial, evaluating migration of a cemented vitamin E-stabilized highly crosslinked component compared with a standard polyethylene component in reverse hybrid total hip arthroplasty. Bone and Joint Journal 2019;101-B:1192-8.
317.Smith BC, Crisp CC, Kleeman SD, et al. Uterosacral Ligament Suspension Versus Robotic Sacrocolpopexy for Treatment of Apical Pelvic Organ Prolapse. Female Pelvic Medicine and Reconstructive Surgery 2019;25:93-8.

318. Takeuchi Y, Mabe K, Shimodate Y, et al. Continuous anticoagulation and cold snare polypectomy versus heparin bridging and hot snare polypectomy in patients on anticoagulants with subcentimeter polyps. Annals of Internal Medicine 2019;171:229-37.

319. Thuijs DJFM, Kappetein AP, Serruys PW, et al. Percutaneous coronary intervention versus coronary artery bypass grafting in patients with three-vessel or left main coronary artery disease: 10-year follow-up of the multicentre randomised controlled SYNTAX trial. The Lancet 2019;394:1325-34.

320. Treasure T, Barnard S, Batchelor T, et al. Pulmonary Metastasectomy versus Continued Active Monitoring in Colorectal Cancer (PulMiCC): A multicentre randomised clinical trial. Trials 2019;20 (1) (no pagination).

321. Turk AS, Siddiqui A, Fifi JT, et al. Aspiration thrombectomy versus stent retriever thrombectomy as first-line approach for large vessel occlusion (COMPASS): a multicentre, randomised, open label, blinded outcome, non-inferiority trial. The Lancet 2019;393:998-1008.

322. Valdes-Chavarri M, Kedev S, Neskovic AN, et al. Randomised evaluation of a novel biodegradable polymer-based sirolimus-eluting stent in ST-segment elevation myocardial infarction: the MASTER study. Eurointervention 2019;14:e1836-e42.

323. Vos NS, Fagel ND, Amoroso G, et al. PaclitaxelCoated Balloon Angioplasty Versus Drug-Eluting Stent in Acute Myocardial Infarction: The REVELATION Randomized Trial. JACC: Cardiovascular Interventions 2019;12:1691-9.

324. Werner YB, Hakanson B, Martinek J, et al. Endoscopic or surgical myotomy in patients with idiopathic Achalasia. New England Journal of Medicine 2019;381:2219-29.

325. Wu Y, Shen L, Yin J, et al. Twelve-month angiographic and clinical outcomes of the XINSORB bioresorbable sirolimus-eluting scaffold and a metallic stent in patients with coronary artery disease. International Journal of Cardiology 2019;293:61-6.

326. Yu J, Huang C, Sun Y, et al. Effect of Laparoscopic vs Open Distal Gastrectomy on 3-Year Disease-Free Survival in Patients with Locally Advanced Gastric Cancer: The CLASS-01 Randomized Clinical Trial. JAMA - Journal of the American Medical Association 2019;321:1983-92. 327.Zaman A, de Winter RJ, Kogame N, et al. Safety and 
efficacy of a sirolimus-eluting coronary stent with ultra-thin strut for treatment of atherosclerotic lesions (TALENT): a prospective multicentre randomised controlled trial. The Lancet 2019;393:987-97.

328. Beguinot M, Botchorishvili R, Comptour A, et al. Minilaparoscopic Total Hysterectomy in Current Practice Feasibility and Benefits: A Unicentric, Randomized Controlled Trial. Journal of Minimally Invasive Gynecology 2020;27:673-80.

329. Bosiers M, Setacci C, De Donato G, et al. ZILVERPASS Study: ZILVER PTX Stent vs Bypass Surgery in Femoropopliteal Lesions. Journal of Endovascular Therapy 2020;27:287-95.

330. Brown SGA, Ball EL, Perrin K, et al. Conservative versus interventional treatment for spontaneous pneumothorax. New England Journal of Medicine 2020;382:405-15.

331. Ganyukov V, Kochergin N, Shilov A, et al. Randomized Clinical Trial of Surgical vs. Percutaneous vs. Hybrid Revascularization in Multivessel Coronary Artery Disease: Residual Myocardial Ischemia and Clinical Outcomes at One Year - Hybrid coronary REvascularization Versus Stenting or Surgery (HREVS). Journal of Interventional Cardiology 2020;2020 (no pagination).

332. Insausti I, Saez de Ocariz A, Galbete A, et al. Randomized Comparison of Prostatic Artery Embolization versus Transurethral Resection of the Prostate for Treatment of Benign Prostatic Hyperplasia. Journal of Vascular and Interventional Radiology 2020.

333.Itkonen Freitas AM, Mentula M, Rahkola-Soisalo P, et al. Tension-Free Vaginal Tape Surgery versus Polyacrylamide Hydrogel Injection for Primary Stress Urinary Incontinence: A Randomized Clinical Trial. Journal of Urology 2020;203:372-8.

334.Jensen LO, Maeng M, Raungaard B, et al. Randomised Comparison of the Polymer-Free Biolimus-Coated BioFreedom Stent with the Ultrathin Strut Biodegradable Polymer Sirolimus-Eluting Orsiro Stent in an AllComers Population Treated with Percutaneous Coronary Intervention: The SORT OUT IX Trial. Circulation 2020.

335. Katai H, Mizusawa J, Katayama H, et al. Survival outcomes after laparoscopy-assisted distal gastrectomy versus open distal gastrectomy with nodal dissection for clinical stage IA or IB gastric cancer (JCOG0912): a multicentre, noninferiority, phase 3 randomised controlled trial. The Lancet Gastroenterology and Hepatology 2020;5:142-51.

336. Khashab MA, Sanaei O, Rivory J, et al. Peroral endoscopic myotomy: anterior versus posterior approach: a randomized single-blinded clinical trial. Gastrointestinal
Endoscopy 2020;91:288-97.e7.

337. Kisser U, Lill C, Adderson-Kisser C, et al. Total versus subtotal tonsillectomy for recurrent tonsillitis-a prospective randomized noninferiority clinical trial. Acta Oto Laryngologica 2020.

338. Leclercq F, Robert P, Akodad M, et al. Prior Balloon Valvuloplasty Versus Direct Transcatheter Aortic Valve Replacement: Results From the DIRECTAVI Trial. JACC: Cardiovascular Interventions 2020;13:594-602.

339. Li C, Yang Y, Han Y, et al. Comparison of the Ultrathin Strut, Biodegradable Polymer Sirolimus-eluting Stent With a Durable Polymer Everolimus-eluting Stent in a Chinese Population: The Randomized BIOFLOW VI Trial. Clinical Therapeutics 2020.

340. Menown IBA, Mamas MA, Cotton JM, et al. First clinical evidence characterizing safety and efficacy of the new CoCr Biolimus-A9 eluting stent: The Biomatrix AlphaTM registry. IJC Heart and Vasculature 2020;26 (no pagination).

341. Onda T, Satoh T, Ogawa G, et al. Comparison of survival between primary debulking surgery and neoadjuvant chemotherapy for stage III/IV ovarian, tubal and peritoneal cancers in phase III randomised trial. European Journal of Cancer 2020;130:114-25.

342. Park SM, Park J, Jang HS, et al. Biportal endoscopic versus microscopic lumbar decompressive laminectomy in patients with spinal stenosis: a randomized controlled trial. Spine Journal 2020;20:156-65.

343.Paul SB, Acharya SK, Gamanagatti SR, et al. Acetic acid versus radiofrequency ablation for the treatment of hepatocellular carcinoma: A randomized controlled trial. Diagnostic and Interventional Imaging 2020;101:101-10. 344. Qi S, Yang E, Bao J, et al. Single-Use Versus Reusable Digital Flexible Ureteroscopes for the Treatment of Renal Calculi: A Prospective Multicenter Randomized Controlled Trial. Journal of Endourology 2020;34:18-24.

345.Reppas L, Arkoudis NA, Spiliopoulos S, et al. Two-Center Prospective Comparison of the Trocar and Seldinger Techniques for Percutaneous Cholecystostomy. AJR American Journal of Roentgenology 2020;214:206-12.

346. Windecker S, Latib A, Kedhi E, et al. Polymer-based or polymer-free stents in patients at high bleeding risk. New England Journal of Medicine 2020;382:1208-18.

347. Youn YJ, Lee JW, Ahn SG, et al. Randomized Comparison of Everolimus- and Zotarolimus-Eluting Coronary Stents With Biolimus-Eluting Stents in All-Comer Patients. Circ Cardiovasc Interv 2020;13:e008525. 